\title{
Değişkenleri Belirleme ve Kontrol Etme Becerisi İçin Bir Test Geliştirme Çalışması: Karma Yöntem Araştırması
}

\author{
Neslihan Çam*, Feride Ercan Yalman**
}

Makale Geliș Tarihi: 02/10/2020

Makale Kabul Tarihi: $31 / 12 / 2020$

DOI: $10.35675 /$ befdergi. 804317

$\ddot{O} z$

Bu çalışmanın amacı, ilköğretim 8. sınıf öğrencilerinin bilimsel süreç becerilerinden değişkenleri belirleme ve kontrol etme becerilerini ölçmeye yönelik test geliştirmektir. Çalışmada karma araştırma yöntemlerinden açıklayıcı ardışık desen kullanılmıştır. Uygulama, ön, pilot ve asıl uygulama olmak üzere ü̧̧ aşamada gerçekleştirilmiştir. Test geliştirme aşamasinda Mersin ilinde bulunan 8. sinıf düzeyinde öğrenim gören toplam 1006 öğrenci (21 ögrenci ön uygulamada, 437 ögrenci pilot uygulamada ve 548 ögrenci asıl uygulamada) sürece dâhil olmuştur. Asıl uygulamadan sonra 53 ögrrenci ile test ile ilgili görüş̧meler yapılmıştır. 24 maddeden oluşan testin ortalama güçlüğü 0,50 değerindedir. Testin KR-20 güvenirlik katsaylsı 0,86 olarak hesaplanmıştır. Bu bağlamda madde analizi sonuçlarına göre, testin amacına hizmet edebilecek ve uygulanabilir bir test olduğu söylenebilir. Öğrenciler tarafindan değişkenler belirlenirken birtakım sorunlarla (dikkatsizlik, soruyu anlamamak vb.) karşılaşılmıştır.

Anahtar Kelimeler: Değişkenleri belirleme ve kontrol etme, test geliştirme, 8. sinıf ögrencileri

\section{A Test Development Study for Identifying and Controlling Variables Skill: A Mixed Method Research}

\begin{abstract}
This study aimed to develop a test to measure $8^{\text {th }}$ graders' ability to identify and control variables from scientific process skills. In the study explanatory sequential design was used that it one of the mixed research designs. Implementation was carried out in three phases as preliminary, pilot and actual implementation. The total implementation of the test was conducted with 1006 (21 in preliminary, 437 in pilot and 548 in actual implementation) $8^{\text {th }}$ graders in Mersin. During the implementation, 54 students were interviewed about test after actual implementation. The average difficulty of the test which consisted of 24 items was calculated to be 0.50 and the KR-20 reliability coefficient was 0.86 . In this context, based on item analysis results, it can be argued that the test is a viable test that can serve its purpose. While identifying variables, some problems (carelessness, not understanding the question, etc.) were encountered by the students.
\end{abstract}

Keywords: Identifying and controlling variables, test development, $8^{\text {th }}$ grade students.)

\footnotetext{
*Mersin Üniversitesi, Eğitim Bilimleri Enstitüsü, Mersin, Türkiye, e-mail: neslihan109@gmail.com, ORCID: 0000-0003-4806-310X

*** Mersin Üniversitesi, Eğitim Fakültesi, Matematik ve Fen Bilimleri Eğitimi Bölümü, Mersin, Türkiye, e-mail: feride@mersin.edu.tr, ORCID: 0000-0003-1037-1473@

Kaynak Gösterme: Çam, N., \& Ercan Yalman, F. (2021). Değişkenleri belirleme ve kontrol etme becerisi için bir test geliştirme çalışması: Karma yöntem araştırması. Bayburt Eğitim Fakültesi Dergisi, 16(32), 410-442.
} 


\section{Giriş}

21. yüzyıl ihtiyaçları bireylerden bilimsel bilgiye ulaşmayı öğrenmelerini, bilimin doğasını anlamalarını ve ürettikleri bilgileri günlük hayatlarına uyarlamalarını beklemektedir. Bu bağlamda bilimin ışığında yeni nesilleri fen okuryazarı bireyler olarak yetiştirmek önem arz etmektedir (Kılınç, 2018). Fen okuryazarı bireylerin bilim üretilirken geçilen aşamaları bilmesi (Jurecki \& Wander, 2012) okulda karşılaşılan anahtar fen kavramlarını ve teorik bilgiyi günlük yaşama aktarabilmesi beklenmektedir (Suryanti, İbrahim \& Lede, 2018; Üstün, Özdemir, Cansız \& Cansız, 2019). Guthrie'ye (1952) göre bilgi, işin bilişsel boyutunu, beceri ise belirli bir sonuca ulaşma boyutunu kapsamaktadır (Akt: Turan 2014). Bu nedenle fen eğitimi üzerine yapılan çalışmalar, beceri boyutuna odaklanılması gerektiğine işaret etmektedir (Aktamış \& Şahin Pekmez, 2011; Celep \& Bacanak 2013; Kılınç, 2018). Bu paydada buluşan bazı araştırmacılar, son yıllardaki yönelimleri de dikkate alarak beceri boyutunun önemini ve etkilerini özümsemişlerdir. Bu becerilerden en önemlilerinden biri bilimsel süreç becerileridir (Harlen, 1999). Bu nedenledir ki bilimsel süreç becerileri, fen bilimleri öğretim programında bir öğrenme alanı olarak tanımlanmaktadır (Milli Eğitim Bakanlığı [MEB], 2018). Bununla birlikte PISA 2006 raporunda bilimsel süreç becerileri bilim okuryazarlığının üç boyutundan biri olarak görülmektedir (Organisation for Economic Co-operation and Development [OECD], 2007). Çünkü bilimin, bilimsel süreç becerileriyle daha iyi anlaşılabileceği düşünülmektedir (Prayitno, Corebima, Susilo, Zubaidah \& Ramli, 2017).

Bilimsel süreç becerileri ile ilgili, tarihsel süreç içinde farklı araştırmacılar tarafından farklı gruplandırmalar yapılmıştır. Çepni, Ayas, Johnson ve Turgut (1997) tarafından bilimsel süreç becerileri temel, nedensel ve deneysel süreçler olmak üzere üç sınıfa ayrılırken Martin (1997) tarafindan bilimsel süreç becerileri temel ve bütünleştirilmiş beceriler şeklinde sınıflandırılmıştır. Alanyazında bilimsel süreç becerilerini temel ve üst düzey beceriler olarak iki kategoride sinıflandıran araştırmacilar da mevcuttur (Bailer, Ramig \& Ramsey, 1995; Germann, 1994; Lakin \& Wellington, 1994; Lati, Supasorn \& Promarak, 2012; Mohd Saat, 2004; Rubin \& Norman, 1992). Bilimsel süreç becerileri hangi sınıflandırmaya tabi tutulursa tutulsun tüm sınıflandırmalarda bilimsel süreç becerilerinin alt boyutu olan değişken belirleme ve kontrol etme becerisi kendisine üst düzey becerilerin arasında bir yer edinmiştir. Çünkü değişkenlerin belirlenmesi ve kontrol edilmesi bilimsel bilgi üretilirken deneysel çalışmaların zeminini oluşturmakta ve birçok beceriyi içinde barındırmaktadır. Carin'in (1993) tanımlamasına göre değişkenleri belirleme ve kontrol etme becerisi, bir bilim insanı edasıyla deney anındaki tüm etkenleri göz önünde bulundurarak etkenler arasındaki ilişkileri neden-sonuç ekseninde irdelemektir. Bu bağlamda muhakeme yapmayı sağlayan değişkenleri değiştirme ve kontrol etme becerisi 2018 fen bilimleri öğretim programında açık bir şekilde belirtilmektedir. Ayrıca bilimsel süreç becerilerinin konu alanlarına yayılması gerektiği ifade edilmektedir (MEB, 2018). Bir diğer ifade ile konu bağlamında 
bilimsel süreç becerilerini ele almak yerine mümkün olan her firsatta bu becerilerin kazandırılmaya çalışılması tavsiye edilmektedir.

Araştırmacıların bilimsel süreç becerileri ölçüm aracına dair farklı tercihleri söz konusudur (Aydınlı, Dökme, Ünlü, Öztürk, Demir \& Benli, 2011). Örneğin Durmaz ve Mutlu (2012) açık uçlu soruları daha geçerli bulurken, Ateş (2005) çoktan seçmeli soruları daha geçerli bulmaktadır. Bilimsel süreç becerileri genellikle çoktan seçmeli testlerle ölçülmüştür (Aydoğdu, Tatar, Yıldız \& Buldur, 2012; Şardağ, Kocakülah, 2016). Açık uçlu sorularla geliştirilen testler olsa da bu testlerin sayıca az olduğu söylenebilir (Aydoğdu, 2006; Durmaz \& Mutlu 2012). Değişkenleri belirleme ve kontrol etme becerisini bilimsel süreç becerilerinin bir alt boyutu niteliğinde olması nedeniyle ve spesifik bir beceriyi ölçmesi sebebi ile ulusal alanyazında sınırlı sayıda çalışma bulunmaktadır. Söz konusu beceriyi başlı başlına ele alan üç çalışmaya (Ateş, 2005; Temiz \& Tan 2007; Bağcı Kılıç, Yardımcı \& Metin, 2009) rastlanmıştır. Temiz ve Tan'ın (2007) çalışması ortaöğretim kademesiyle gerçekleştirilmiştir. Diğer iki çalışma ise öğretmen adaylarıyla gerçekleştirilmiştir. Tablo 1'de ilgili çalışmalar ile ilgili bilgiler verilmiştir.

Tablo 1.

Değişkenleri Belirleme ve Kontrol Etme Becerisi Ölçeklerine İlişkin Bilgiler

\begin{tabular}{llll}
\hline Testin adı & Araştırmacı & Yıl & Katılımcı grubu \\
\hline $\begin{array}{l}\text { Değişkenleri belirleme ve kontrol } \\
\text { etme testi }\end{array}$ & Ateş & 2005 & 3. Sınıf öğretmen adayları \\
\hline $\begin{array}{l}\text { Değişken değiştirme ve kontrol etme } \\
\text { başarı testi }\end{array}$ & Temiz ve Tan & 2007 & Lise 1. Sınıf öğrencileri \\
\hline $\begin{array}{l}\text { Öğretmenlere yönelik bilimsel süreç } \\
\text { becerileri testi }\end{array}$ & $\begin{array}{l}\text { Bağcı Kılıç ve } \\
\text { diğerleri }\end{array}$ & 2009 & 2. Sınıf öğretmen adayları
\end{tabular}

Değişken belirleme ve kontrol etme becerisini farklı değişkenler açısından ele alan Ateş (2005) öğretmen adaylarıyla yapılan çalışmasında öğretmen adaylarının bilimsel süreç becerilerini pek çok değişken açısından (fen tutumu, ailenin ortalama gelir düzeyi, cinsiyet, sınıf düzeyi, bilgisayara sahip olma, lisede sayısal veya sözel alan seçimi) incelenmiştir. Temiz ve Tan (2007) tarafından gerçekleştirilen çalışmada hem açık uçlu hem de çoktan seçmeli soruların yer aldığı test aracılığı ile lise öğrencilerinin değişken belirleme ve kontrol etme becerileri tespit edilmiştir. Bağcı Kılıç ve diğerleri (2009) tarafından öğretmen adaylarıyla gerçekleştirilen çalışmada katılımcılardan senaryolar üzerinden verilen açık uçlu değişken belirleme sorularını cevaplamaları istenmiş ve veri analizi gerçekleştirilmiştir.

\section{Araştırmanın Amacı ve Önemi}

Bilimsel süreç becerilerinin bir alt boyutu olan değişkenleri belirleme ve kontrol etme becerisinin öğrencilere zor kazandırıldığına ilişkin bilgiler alanyazında bulunmaktadır (Ateş \& Bahar, 2002; Çimen, 2018; Irwanto, Rohaeti \& Prodjosantoso, 2018; Kılınç, 2018, Temiz, 2020; Tosun, 2019). Örneğin Irwanto, Rohaeti \& Prodjosantoso (2018) çalışmalarında değişken belirleme becerisinin diğer bilimsel süreç becerilerinden çok 
daha düşük düzeyde olduğunu belirtirken Ateş ve Bahar (2002) söz konusu becerilerin öğrenciler tarafından anlaşılamadığını ve kavramsal karmaşa yaşandığını ifade etmektedir. Araştırmacılar bağımlı, bağımsız ve kontrol edilen değişken ifadelerinin algılanamamasında terminolojinin de etkisinin olduğunu ileri sürmektedir. Değişkenlerin istatistiki adlandırmasının (bağımlı değişken, bağımsız değişken vs.) öğrenciler tarafından değişkenlerin anlaşılmasını zorlaştırdığı ve değişkenlerin karıştırılmasına sebep olduğu düşünülmektedir. $\mathrm{Bu}$ sebeple değişkenleri karıştırmamak için değişkenlerin farklı şekilde adlandırılması önerisinde bulunan Ateş (2005) bağımlı değişken yerine "cevap veren değişken” teriminin daha anlamlı olduğunu ifade etmektedir. Alanyazında araştırmacılar tarafından daha farklı adlandırmalar da önerilmektedir. Örneğin genellikle bağımsız değişken için etkileyen, sebep olan veya değiştirilen değişken ifadeleri kullanılırken, bağımlı değişken için etkilenen, sonuç olan veya ölçülen değişken ifadeleri tavsiye edilmektedir (Aydoğdu, 2006; Bağcı Kılıç, Yardımcı \& Metin, 2009; Geban, Aşkar \& Özkan, 1992).

Yukarıda adı geçen çalışmalar değişken belirleme ve kontrol etme becerisini ele alan çalışmalar olsa da alanyazında ortaokul öğrencileri için spesifik olarak değişkenleri belirleme ve kontrol etme becerisini ölçebilmek için test ya da ölçek geliştirme çalışmasına ulaşılamamıştır. Bu çalışmanın amacı, ilköğretim 8. sınıf öğrencilerinin bilimsel süreç becerilerinden değişkenleri belirleme ve kontrol etme becerilerini ölçmeye yönelik test geliştirmektir. Geliştirilen testin alanyazındaki boşluğu doldurabileceği ve alanyazına katkı sağlayabileceği düşünülmektedir. Söz konusu beceri, öğrencilerin sıkıntıya düştüğü ve zorlandığı bir beceri (Seetee, Coll, Boonprakob \& Dahsah, 2016) olduğundan öğrencilerin bireysel farklılıkları göz önünde bulundurularak, değişkenleri belirleme ve kontrol etme becerisini bütünüyle irdelemenin, öğrencilerin zorlanma nedenlerine odaklanmanın ve bu beceriyi geliştirici alternatifler üretmenin gerekli olduğu düşünülmektedir. Ayrıca birçok test geliştirme çalışmasında nicel kısma ağırlık verilirken, nitel bulgulardan pek yararlanılmadığı gözlenmektedir. Hâlbuki test geliştirme gibi nicel yöntemin doğasına uygun bir sürece nitel bulgular da 1şık tutabilmektedir. Bu şekilde daha sağlam bir ölçme aracının geliştirilebileceği düşünülmektedir. Bu nedenle bu araştırmada test geliştirme süreci sadece nicel sonuçlar üzerinden ilerlememiş ve nitel veriler de toplanarak derinlemesine bilgiler sunan bir veri seti elde etmeye çalışılmıştır. $\mathrm{Bu}$ bağlamda karma araştırma yöntemleri ile test geliştirme sürecinin alanyazına daha nitelikli bilgiler sunabileceği umulmaktadır.

\section{Yöntem}

\section{Araştırma Deseni}

$\mathrm{Bu}$ araştırma, karma araştırma yöntemine göre tasarlanmıştır. Karma yöntemde nitel ve nicel verilerin birleşimi sayesinde çok daha güçlü sonuçlar elde edilebilmektedir (Creswell \& Plano Clark, 2018, s.10). Araştırmada Creswell ve Plano Clark'ın (2018, s. 90) sınıflandırmasındaki karma yöntem çeşitlerinden açıklayıcı ardışık desen esas 
alınmıştır. Söz konusu desen alanyazında nitel takip yaklaşımı olarak da isimlendirilmektedir (Morgan, 1998). Genellikle ölçme aracı geliştirme sürecinde tercih edilen açıklayıcı ardışık desende önce nicel yöntemler ile veriler toplanmakta ardından nitel veriler toplanmaktadır. Bu sayede nicel verilerin içindeki ilişkiler, örüntüler ve eğilimler nitel veriler aracılığı ile tespit edilebilmektedir (Creswell \& Plano Clark, 2018; s. 91; Plano-Clark \& Ivankova, 2016). Bu doğrultuda değişkenleri belirleme ve kontrol etme testi geliştirme sürecinde nicel aşamalar adım adım takip edilmiş, nitel bulgular da sürece 1ş1k tutmuştur. 8. sınıf öğrencilerinin değişkenleri belirleme ve kontrol etme becerilerini ölçmek amacıyla geliştirilen testin ad, Değişkenleri Belirleme ve Kontrol Etme Testi (DBVKET) olarak belirlenmiştir.

\section{Katılımcilar}

Araştırmada Mersin il merkezi ve ilçelerde öğrenim gören 8. sınıf düzeyindeki 1006 öğrenci test geliştirme sürecine dâhil olmuştur. Ön uygulama 21 öğrenci, pilot uygulama 437 öğrenci, asıl uygulama ise 548 öğrenci ile gerçekleştirilmiştir. Asıl uygulamada yer alan okul ve öğrenci dağılımı Tablo 2'de sunulmuştur.

Tablo 2.

Çalışmanın Örneklemine İlişkin Bilgiler (Asıl Uygulama)

\begin{tabular}{lll}
\hline Verinin Toplandığı ilçe & Okul niteliği & Öğrenci sayısı \\
\hline Mersin (Gülnar ilçesi) & Sosyoekonomik düzeyi düşük & 61 \\
\hline Mersin (Erdemli ilçesi) & Sosyoekonomik düzeyi orta & 36 \\
\hline Mersin (Silifke ilçesi) & Sosyoekonomik düzeyi düşük & 38 \\
\hline Mersin (Mut ilçesi) & Sosyoekonomik düzeyi düşük & 17 \\
\hline Mersin (Merkez) & Sosyoekonomik düzeyi düşük & 42 \\
\hline Mersin (Merkez) & Sosyoekonomik düzeyi orta & 134 \\
\hline Mersin (Merkez) & Sosyoekonomik düzeyi orta & 69 \\
\hline Mersin (Merkez) & Sosyoekonomik düzeyi yüksek & 63 \\
\hline Mersin (Merkez) & Sosyoekonomik düzeyi yüksek & 88 \\
\hline Toplam & & 548 \\
\hline
\end{tabular}

Mersin ilinde araştırma kapsamında ulaşılan dokuz devlet okulundan beş ortaokul il merkezinde, dört ortaokul ise merkeze uzak ilçelerde yer almaktadır. Testin ön uygulaması Mersin il merkezine bağlı bir devlet okulunda 21 öğrenci ile pilot uygulama ise il merkezine bağlı altı devlet okulunda 437 öğrenci ile gerçekleştirilmiştir. Asıl uygulama ise dokuz okuldan toplamda 548 öğrenci araştırma sürecine dâhil olmuştur. Araştırmalarda ulaşılan katılımcı sayısı arttıkça gerçek puanlara daha fazla yaklaşılacağı bilinmektedir (Karslı \& Ayas, 2013). Bir diğer ifade ile araştırmada elde edilen verileri genelleyebilmek adına çok sayıda öğrenciye ulaşmak gerekmektedir. Bu sebep ile kolay ulaşılabilir örnekleme yoluyla çalışma 
grubuna ulaşılmak istenmiştir. Kolay ulaşılabilir örneklemede araştırmacı kendisine veri toplamada uygun olan alanı seçerek çalışmaya hız ve pratiklik katabilmektedir (Yıldırım \& Şimşek, 2018). Bu çalışmada da araştırmacılar dokuz okulun belirlenmesinde kolaylıkla ulaşılabilecek okulları tercih etmiştir. Bu araştırmadaki veriler değişkenleri belirleme ve kontrol etme testi ve görüşme soruları aracılığı ile elde edilmiştir. Bahsedilen veri toplama araçları ve verilerin toplanma süreci ayrıntılı şekilde sunulmuştur.

\section{Verilerin Toplanması}

\section{Test geliştirme süreci}

$\mathrm{Bu}$ bölümde DBVKET geliştirilirken izlenen aşamalardan bahsedilmektedir. Şekil 1'de test geliștirmenin genel süreci özetlenmiştir.

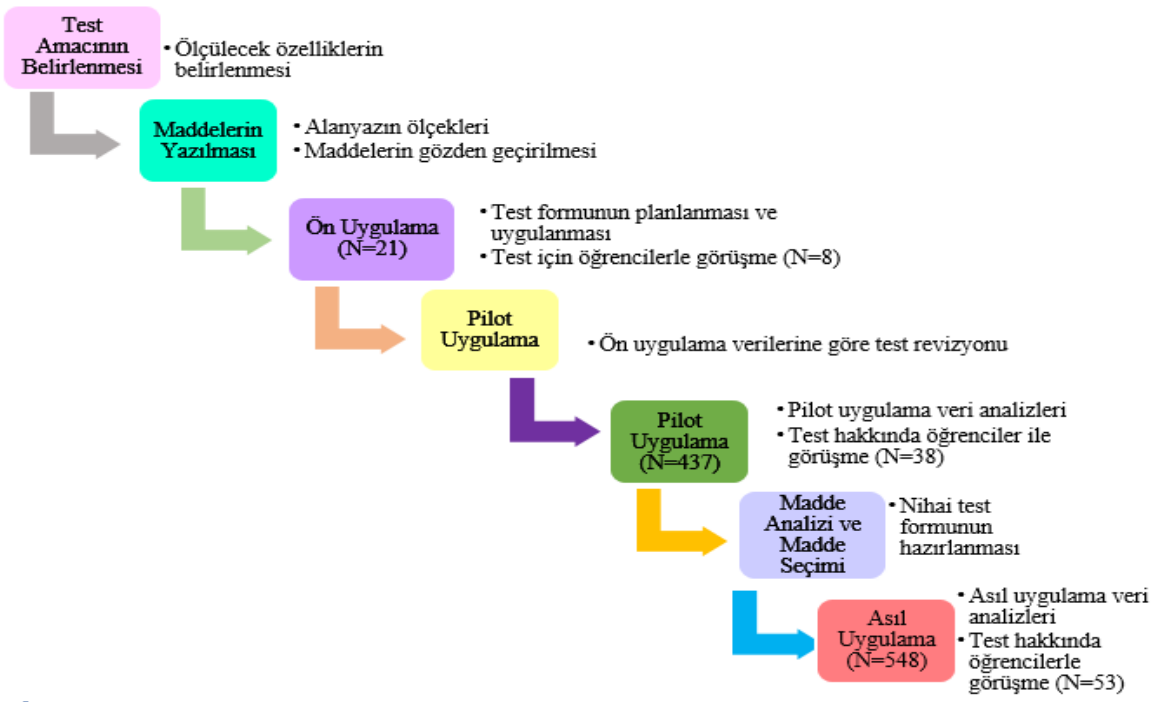

Şekil 1. Test geliştirme süreci

\subsection{Test amacinın belirlenmesi}

DBVKET'nin geliştirilme aşamasında alanyazındaki çalışmalar incelendiğinde ilgili çalışmalarda (Aydoğdu \& Ergin, 2012; Meriç \& Karatay, 2014; Şahintepe, 2018; Öç, 2019; Öztürk, Tezel \& Acat, 2010) söz konusu beceri için benzer soru türlerinin olduğu görülmüştür. Bu çalışmada ise değişken belirleme düzeylerini incelemek için, çoktan seçmeli soru tipinin daha uygun olacağ 1 düşünülmüştür. Çünkü çoktan seçmeli testlerin kapsam geçerliliğinin yüksek olması, puanlayıcı yanlılığına kapalı olması ve aynı zamanda çok kişiye uygulanabilmesi söz konusudur (Turgut \& Baykul, 2010). 


\subsection{Maddelerin yazılması}

Maddelerin yazım aşamasında alanyazındaki ilgili çalışmalar incelenmiş ve 8 . sınıf fen konu alanlarının tümünü kapsayacak şekilde 30 maddeden oluşan taslak form hazırlanmıştır. Alanyazındaki çalışmalarda, değişken belirleme soruları bilimsel süreç becerisi testleri içerisine dağıtılmış halde bulunmaktadır. Bu sebepten, Burns ve diğerleri (1985) tarafindan geliştirilen, Geban ve diğerleri (1992) tarafindan Türkçe'ye uyarlanan bilimsel süreç becerileri testinden (Akt., Serin, 2009) yararlanılmıştır. Test içerisinde araştırmacının özgün soruları mevcuttur. Aynı zamanda TIMMS sorularından ve internetteki alana yönelik sitelerden yararlanılmıştır. Mümkün olduğunca karma sorular sorularak testin her öğrenciye hitap etmesi amaçlanmıştır. Bu doğrultuda DBVKET'nin alt boyutları hipotez kurabilme, bağımlı değişken belirleyebilme, bağımsız değişken belirleyebilme, kontrol değişkeni belirleyebilme ve karma soruları cevaplandırabilme olarak belirtilebilir. Belirtilen alt boyutların soru sayıları test içerisinde eşit tutulmaya çalışılmıştır. Söz konusu alt boyutların ve ölçülmek istenen becerilerin dağılımı bulgular bölümünde yer alan Tablo 4'te gösterilmiştir. Test maddeleri konu alan bilgisinden ve tema çeşidinden bağımsız olarak geliştirilmiştir. Nitekim değişkenleri belirleme ve kontrol etmenin bir beceri olduğu göz önüne alındığında, tek bir konu alanına ya da temaya bağlı olmaksızın beceriyi kazandırmanın önemli olduğu düşünülmektedir.

\section{3. Ön uygulama}

Ön uygulama Mersin'de bulunan bir ilköğretim okulunda 8. sınıfa devam eden 21 öğrenci üzerinde gerçekleştirilmiştir. Fen eğitimi alanında doktora yapmış iki alan uzmanı (öğretim üyesi) ile birlikte testin taslak formunda yer alan 30 soru incelenmiş ve test 27 soruya düşürülmüştür. Testte yer alan çoktan seçmeli maddelerin madde güçlük indeksleri ortalamasının 0.19 , madde ayırt etme indeksleri ortalamasının ise 0.17 olduğu bulunmuştur. KR-20 değeri ön uygulamada hesaplanamamıştır. Test puanlarının ortalamas 19,04 olarak bulunmuştur. Bu aşamada testten alınabilecek en yüksek puan 27 puandır. Uzmanların görüşleri dikkate alınarak gerçekleştirilen ön uygulama sonucunda iki madde testten çıkarılmış, 12 madde revize edilmiştir. Söz konusu 12 madde soruların anlaşılabilirliğini arttırmak, sınıf düzeyine uygun olmasını sağlamak amacıyla revize edilmiştir. Ön uygulama aşamasının sonunda madde sayısı 25 'e düşmüştür. Çalışma gönüllük esasına göre yürütülmüş ve gönüllü sekiz öğrenci belirlenmiştir. Sekiz öğrenciyle yarı yapılandırılmış görüşme gerçekleştirilmiştir. Görüşmelerde fen bilimleri dersine ilgi duyan ve kitap okuyan öğrencilerin testi anlaşılabilir bulduğu, fen bilimleri dersine ilgisi olmadığı belirtilen ve kitap okumadığını dile getiren öğrencilerin testi anlaşılır bulmadığı tespit edilmiştir.

\subsection{Pilot uygulama}

Pilot uygulama Mersin ilinde bulunan altı ilköğretim okulunda 8. sınıfa devam eden 437 öğrenci ile gerçekleştirilmiştir. Bu aşamada testte, 25 tane çoktan seçmeli 
soru yer almaktadır. Pilot uygulama sonucunda KR-20 değeri 0.86 olarak hesaplanmıştır. Madde güçlük indeksleri ortalaması 0.46 ve madde ayırt etme indeksleri ortalaması 0.58 olarak bulunmuştur. Test puanlarının ortalaması 11,22 olarak bulunmuştur. İki alan uzmanı ile birlikte maddelerin nasıl geliştirilebileceği üzerine görüşmeler gerçekleştirilmiş, test maddelerinden üç tanesi revize edilmiş ve sorular üzerinde nihai karara varılarak test asıl uygulamaya hazır hale getirilmiştir. Çalışma gönüllük esasına göre yürütülmüş ve gönüllü 38 öğrenci belirlenmiştir. Bu aşamada 38 öğrencinin teste ilişkin görüşleri alınarak nitel bulgular elde edilmiştir.

\subsection{Madde analizi ve madde seçimi}

Madde analizinde ön uygulama ve pilot uygulamanın sağladığı verilerden yararlanılmıştır. Madde güçlük indeksi (p) ve madde ayırt etme indeksi (rjx) değerleri belirlenerek test maddelerinin işlerliği konusunda fikir edinilmiştir. Görüşme verileri yoluyla öğrencilerin belirttiği sorular tekrar incelenmiştir. Son aşamada 2 alan uzmanı ile birlikte hangi maddelerin test içerisinde kalması gerektiği, hangi maddelerin elenmesi gerektiği üzerine ve asıl uygulamanın nasıl yapılacağı ile ilgili kararlar alınmıştır.

\subsection{Astl uygulama}

Asıl uygulama Mersin ilinde bulunan dokuz ortaokulda 8. sinıfa devam eden 548 öğrenci ile gerçekleştirilmiştir. Asıl uygulama sonucunda tamamlanmış olan testin son hali Ek 1'de verilmiştir.

\section{Görüşmelerin yapılması}

Nitel araştırmada en sık kullanılan araçlardan biri olan görüşme, bu araştırmada nicel verilere 1şık tutması amacıyla bir diğer veri toplama aracı olarak kullanılmıştır. Altı soruluk görüşme formu hazırlanmıştır. İki alan uzmanının görüşüne sunulduktan sonra formun üzerinde belirli düzeltmeler yapılmıştır. Bu düzeltmeler görüşme sorularının seçimi, öğrencilerin anlam ve bilgi düzeyine uygun olup olmaması gibi değerlendirmeleri kapsamaktadır. Öğrencilere yarı-yapılandırılmış görüşme soruları sorulmuştur $\mathrm{Bu}$ sorular uygulaması yapılan değişkenleri kontrol etme becerisi testine yöneliktir. Öğrencilere araştırmacının çalışma içerisindeki rolünden bahsedilmiş ve çalışmanın içeriğine yönelik bilgiler verilmiştir. Çalışma gönüllük esasına göre yürütülmüştür. Veriler ses kayıt cihazı ile kayıt altına alınmıştır. Ön uygulama sırasında yapılan görüşmeler yüz yüze gerçekleştirilmiştir. Pilot uygulamada görüşme soruları, görüşme formu şeklinde uygulanmıştır. Pilot uygulama görüşmelerinde öğrencilerin teste yönelik fikirlerini daha fazla ortaya çıkardığı ve kendilerini daha rahat ifade edebildiği belirlenmiştir. Bu yüzden asıl uygulamada da nitel verilere görüşme formu ile ulaşılmasına karar verilmiştir. Görüşme soruları Ek 2'de verilmiştir. 


\section{Geçerlik ve Güvenirlik}

Değişkenleri belirleme ve kontrol etme testi geliştirilirken kapsam geçerliliğini sağlamak açısından fen eğitimi alanında başlangıçta beş uzmanın görüşüne başvurulmuştur. Bahsedilen uzmanlar testi format, seviye, ölçülen değişken türü ve anlaşılabilirlik açısından değerlendirmiştir. Bunun dışında bir Türkçe öğretmeni, üç fen bilimleri öğretmeninin teste dair görüşleri alınmıştır. Araştırmacının farklı zaman aralıklarında verileri analiz etmesinin güvenirliği arttıran bir diğer faktör olduğu düşünülmektedir. Değişkenleri belirleme ve kontrol etme testinin pilot uygulama sonucunda KR-20 değeri 0.86 olarak hesaplanmıştır. Çalışmalarda güvenirlik açısından 0.70 ve üzeri bir değer makul bir değer olarak kabul edilmektedir (Büyüköztürk, 2010). Değişkenleri belirleme ve kontrol etme testi asıl uygulama sonucunda da KR-20 değeri 0,86 olarak hesaplanmıştır.

Araştırmanın nitel boyutunda ise nitel veri analizleri farklı aşamalarda tekrarlanmış ve analiz sürecinde iki araştırmacı görev almıştır. Bununla birlikte geçerliği, güvenirliği, inandırıcılığı ve aktarılabilirliği sağlayabilmek adına ham verilerden alıntılar yaparak bulgular kısmında sunulmuştur. Katılımcıların mahremiyetini zedelememek ve etik kurallara uymak adına katılımcı isimleri belirtilmemiş ve $\ddot{O}_{1}, \ddot{O}_{2}$ gibi kodlar kullanılmıştır. İki araştırmacının analiz sürecindeki görüş birliği ve görüş ayrılığı olan noktalar belirlenmiştir. Miles ve Huberman (1994) tarafından önerilen uyum yüzdesi hesaplanmıştır. Söz konusu uyum katsayısı 0,88 olarak hesaplanmıştır. Miles ve Huberman (1994) araştırmacılar arasında 0,70 ve üzerinin kabul edilebilir bir değer olduğunu ifade etmektedir. Yukarıda bahsedilen tüm uygulamaların geçerlik ve güvenirliğe kanıt teşkil edebileceği düşünülerek test geliştirme sürecinin sağlıklı bir şekilde ilerlediği söylenebilir.

\section{Verilerin Analizi}

Verilerin analizi için, SPSS 22.0 paket programı ve Microsoft Office Excel 2013 kullanılmıştır. Doğru cevaplar 1 puan üzerinden, yanlış cevaplar 0 puan üzerinden değerlendirilirken, boş cevaplar F, iki seçenek birlikte işaretlenmiş olan cevaplar $G$ (geçersiz) olarak kodlanmıştır. Toplanan nicel veriler için maddelerin güçlüğüne (p), madde ayırt etme (rjx), yapı geçerliğine ve KR-20 güvenirlik katsayılarına bakılmıştır.

Madde güçlüğü (p) 0 ile 1 arasında değişen bir değere sahiptir. Madde güçlük indeksine (p) ilişkin alanyazındaki kriteler göz önünde bulundurulduğunda söz konusu değerin 0'a yakın olması maddenin zor olduğunu işaret ederken 1'e yakın olması maddenin kolay olduğuna işaret etmektedir (Gönen, Kocakaya ve Kocakaya, 2011; Kilmen, 2014). Eşik değerleri göz önünde bulundurulduğunda madde güçlük indeksi 0,35 'ten küçük ise maddelerin zor ve 0,85 'ten büyük ise maddelerin kolay olduğu ifade edilmektedir (Ayas, 2009).

Madde ayırt etme indeksi (rjx) -1 ile +1 arasında değişen bir değere sahiptir. Alanyazındaki kriterler dikkate alındığında söz konusu değerin 0,40 ve yukarısı 
olduğunda hazırlanan maddenin çok iyi ve kabul edilebilir bir seviyede olduğu belirtilmektedir (Tekin, 2010). Bununla birlikte madde ayırt etme değerinin 0,19'un altında olması ya maddenin çok güçlü düzenlemeye ihtiyaç duyduğu ya da testten çıkartılması gerektiği şeklinde yorumlanmaktadır. Düzenlemeye ihtiyaç duymayan, sağlıklı bir maddenin ayırt etme indeksinin 0,30'un üzerinde çıkması beklenmektedir (Kilmen, 2014; Özçelik, 2010; Tekin, 2010).

24 maddelik testte her bir sorunun ayırt etme ve güçlük indeksleri ayrıca hesaplanmıştır. Bununla birlikte en yüksek puanı alan \%27'lik üst grup ile en düşük puanı alan \%27'lik alt grubun cevapları ayrıca ele alınmıştır. Ön uygulama sonuçlarına göre madde analizleri değerlendirildiğinde alanda fikirlerine başvurulan beş alan uzmanın da görüşleri dikkate alınarak 5 ve 9. maddeler testten çıkarılmıştır. Çünkü ilgili maddeler madde güçlük indeksi ve madde ayırt etme indeksi açısından arzu edilen normal değerleri sağlayamamıştır. 1, 7, 8, 10, 11, 14, 15, 18, 20, 21, 22, 23. maddeleri kelime seçimi, test düzeni ve anlam bütünlüğü açısından düzenlenmiştir. Ön uygulamada 25 madde olan test, pilot uygulamada 24 maddeye indirgenmiştir. Test puanlarının ortalaması ön uygulamada 9,04 olarak bulunmuştur. Test puanlarının ortalaması pilot uygulamada 11,22 ve asıl uygulamada ise 12,8 olarak hesaplanmıştır. Alanyazındaki kriterlere göre 20 maddelik bir testin ortalamasının yaklaşık 10 olması arzu edilmektedir (Alkan Dilbaz, Özgelen \& Yanpar Yelken, 2012). Bu açıdan değerlendirildiğinde yukarıda belirtilen değerlerin alanyazındaki kriterlere paralellik gösterdiği ve test geliştirme sürecinde beklentiyi karşılar düzeyde olduğu düşünülmektedir. Pilot uygulama sonuçlarına göre madde analizleri iki alan uzmanıyla ve araştırmacılar ile birlikte gerçekleştirilmiştir. Maddelerin madde güçlük indeksi ve madde ayırt etme indeksi göz önüne alınarak testin 2, 9 ve 11 . maddeleri revize edilmiş ve belirli alternatifler üretilmiştir. Diğer maddeler üzerinde herhangi bir değişiklik yapılmamıştır. Asıl uygulamada ise 24 maddeden oluşan test, madde kaybına uğramadan 24 madde ile sabit kalmıştır ve testin son hali elde edilmiştir.

Araştırmanın nitel boyutu ise içerik analizi ile analiz edilmiştir. Toplanan veriler transkript edilerek kodlanmış, kodlamalar ise matris oluşturularak analiz edilmiştir. Kod oluşturma sürecinde araştırmacılar farklı zaman dilimlerinde, tekrar verileri analiz etmiştir. Kodlardan temalara ulaşılmıştır. Bu süreçte matrisler aracılığı ile nitel verilerdeki örüntüler yakalanmaya çalışılmıştır.

\section{Bulgular ve Yorum}

Araştırmanın bulgular kısmında asıl uygulama bulgularına yer verilmiştir. Asıl uygulamanın nicel ve nitel yöntem kısmına ilişkin sonuçlar yorumlanarak sırasıyla verilmiştir. Öncelikle araştırmanın birinci kısmı olan nicel kısma yönelik veriler sunularak değişkenleri belirleme ve kontrol etme testinin madde analizleri verilmiştir. Ardından ikinci kısma yönelik veriler sunularak öğrencilerin teste yönelik görüşlerine yer verilmiştir. 


\section{Nicel Bulgular}

Değişkenleri belirleme ve kontrol etme testi (DBVKET) asıl uygulamanın sonuçlarına göre yapılan madde analizleri Tablo 3 ve 4 'te verilmiştir. Tablo 3 'te değişkenleri belirleme ve kontrol etme testine (DBVKET) ilişkin betimsel istatistikler verilmiştir.

Tablo 3.

Nihai Teste İliskin Betimsel İstatistikler

\begin{tabular}{ccccccccc}
\hline $\mathrm{N}$ & Ortalama & Mod & $\begin{array}{c}\text { Standart } \\
\text { Sapma }\end{array}$ & Varyans & Min & Max. & $\begin{array}{c}\text { Basıklık } \\
\text { Katsayıs1 }\end{array}$ & $\begin{array}{c}\text { Çarpıklık } \\
\text { Katsayıs1 }\end{array}$ \\
\hline 548 & 12,8 & 9,00 & 5,66 & 32,00 & 1,00 & 24,00 & 0,22 & $-0,98$
\end{tabular}

Tablo 3’teki sonuçlara göre testin ortalaması 12,8 olarak bulunmuştur. Puanların en düşüğü 1 , en yükseği ise 24 olduğundan dizinin genişliği 23 'tür. Testte medyan 9 , mod 9, standart sapma 5,66 olarak hesaplanmıştır.

Tablo 4'te DBVKET maddelerinin konu alanlarına ve ölçtüğü beceri türüne dağılımına yer verilmiştir. Bununla birlikte test maddelerinin madde güçlük (p) ve madde ayırt etme (rjx) değerleri verilerek madde analizlerine yer verilmiştir. Teste dâhil edilecek maddelerin belirlenmesinde Tablo 4 'te yer alan değerler ölçüt olarak alınmış̧ır.

Tablo 4.

Nihai Teste Ilişkkin Madde Analizleri

\begin{tabular}{llllll}
\hline $\begin{array}{l}\text { Madde } \\
\text { No }\end{array}$ & Konu alanı & Ölçülen beceri & $\begin{array}{l}\text { Madde } \\
\text { güçlüğü }(\mathrm{p})\end{array}$ & $\begin{array}{l}\text { Madde ayırt } \\
\text { etme (rjx) }\end{array}$ & Sonuç \\
\hline 1 & Fiziksel olaylar & Karma & 0,38 & 0,43 & Çok iyi \\
2 & Fiziksel olaylar & Karma & 0,50 & 0,60 & Çok iyi \\
3 & Canlılar ve yaşam & Hipotez kurma & 0,66 & 0,44 & İyi \\
4 & Fiziksel olaylar & Karma & 0,57 & 0,60 & Çok iyi \\
5 & Madde ve doğası & Bağımlı değişken & 0,35 & 0,38 & İyi \\
6 & Canlılar ve yaşam & Karma & 0,49 & 0,63 & Çok iyi \\
7 & ---- & Karma & 0,48 & 0,58 & Çok iyi \\
8 & Fiziksel olaylar & Hipotez kurma & 0,62 & 0,56 & Çok iyi \\
9 & Canlılar ve yaşam & Hipotez kurma & 0,30 & 0,40 & İyi \\
10 & Canlılar ve yaşam & Bağımlı değişken & 0,55 & 0,72 & Çok iyi \\
11 & Canlılar ve yaşam & Kontrol değişkeni & 0,30 & 0,50 & İyi \\
12 & Canlılar ve yaşam & Bağımsız değişken & 0,43 & 0,77 & Çok iyi \\
13 & Canlılar ve yaşam & Hipotez kurma & 0,58 & 0,76 & Çok iyi \\
14 & Canlılar ve yaşam & Kontrol değişkeni & 0,40 & 0,65 & Çok iyi
\end{tabular}




\begin{tabular}{llllll}
15 & Canlılar ve yaşam & Bağımlı değişken & 0,52 & 0,80 & Çok iyi \\
16 & Canlılar ve yaşam & Bağımsız değişken & 0,44 & 0,72 & Çok iyi \\
17 & Canlılar ve yaşam & Kontrol değişkeni & 0,46 & 0,52 & Çok iyi \\
18 & Canlılar ve yaşam & Bağımlı değişken & 0,54 & 0,73 & Çok iyi \\
19 & Canlılar ve yaşam & Hipotez kurma & 0,56 & 0,60 & Çok iyi \\
20 & Canlılar ve yaşam & Bağımsı değişken & 0,52 & 0,76 & Çok iyi \\
21 & Madde ve doğası & Hipotez kurma & 0,35 & 043 & Çok iyi \\
22 & Madde ve doğası & Kontrol değişkeni & 0,43 & 0,78 & Çok iyi \\
23 & Madde ve doğası & Bağımlı değişken & 0,51 & 0,65 & Çok iyi \\
24 & Madde ve doğası & Bağımsız değişken & 0,48 & 0,72 & Çok iyi \\
\hline
\end{tabular}

Tablo 4 incelendiğinde, DBVKET içerisinde en fazla "canlılar ve yaşam" konu alanına yönelik test maddelerine yer verildiği görülmektedir. Bunun dışında "fiziksel olaylar ve madde ve doğası" test maddelerinin diğer konu alanları olduğu görülmektedir. Test maddelerinin ölçtüğü beceriler bağımlı değişken belirleyebilme, bağımsız değişken belirleyebilme, kontrol değişkeni belirleyebilme, uygun hipotezleri kurabilme ve karma sorular (bağımlı değişken, bağımsız değişken, hipotez kurabilme vb.) olarak sınıflandırılabilir. Tabloda ölçülen becerilerin dağılımının homojen olduğu söylenebilir. Madde analizine göre madde güçlük (p) ve madde ayırt etme indeksleri değerleri sonucunda 20 maddenin çok iyi, 4 maddenin iyi olduğu yorumu yapılabilir.

Analizler sonucunda elde edilen sonuçlara göre, DBVKET'ni oluşturan maddeler için madde güçlük indeksleri 0,3 ile 0,7 arasında değişmektedir. Testin ortama güçlüğü 0.50 değerindedir. Tablodaki verilere göre testte en zor maddeler olan 5. ve 21. maddenin güçlük indeksleri $0,35^{\prime}$ 'dir. Bu değer katılımcıların \%35'inin 5. ve 21 . soruya doğru, \%65'inin yanlış cevap verdiğini ifade etmektedir. En kolay madde ise 0,66 güçlük indeksi ile 3 . maddedir. Genel itibariyle, başarı testlerinde ortalama güçlük indeksinin 0,50 civarında olması beklenmektedir (Atılgan, Kan \& Doğan, 2009; Gönen vd., 2011; Özçelik, 2010). Bu bakımdan DBVKET'nin ortalama güçlügünün 0,50 olarak bulunması bir testin gereklerinin karşılanması açısından önemlidir.

Maddelerin ayırt etme indeksi sonuçlarına bakıldığında, bu değerin 0,3 (madde 5) ile 0,7 (madde 10,12,14,17, 18, 22, 23 ve 24) aralığında olduğu görülmektedir. DBVKET'nin ortalama ayırt etme indeksi ise 0.58 olarak bulunmuştur. Bir testte maddelerin ayırt edicilik noktasında kabul görebilmesi için 0,30 'dan büyük olması gerekmektedir (Kilmen, 2014). Bu kriterlere göre hazırlanan testten çıkarılması gereken bir madde bulunmadığ 1 söylenebilir. 
DBVKET'nin iç tutarlılığını belirlemek amacıyla, KR-20 güvenirlik katsayısı hesaplanmıştır. Teste ait KR-20 güvenirlik katsayısı bu çalışma için 0,86 olarak hesaplanmıştır. Araştırmalarda kullanılabilecek ölçme araçları için güvenirlik düzeyi alt sınırının 0,70 olması (Büyüköztürk, 2010; Özçelik, 2010; Pilten, 2008) gerekmektedir. Bu çalışmada bulunan 0,86 güvenirlik oranı kabul edilebilir bir sonuç ortaya koymaktadır. Yapılan analizler sonucu elde edilen bulgular, DBVKET'nin değişkenleri belirleme ve kontrol etme becerilerini belirlemede geçerli ve güvenilir bir test olduğuna işaret etmektedir.

\section{Nitel Bulgular}

Çalışmanın nitel kısmında 8. sınıf düzeyinde öğrenim gören 548 öğrenci arasından 53 öğrenci ile görüşmeler gerçekleştirilmiştir. Görüşmelerde öğrencilerin \% 20'si DBVKET'ni kolay, \% 61'i orta ve \%19'u zor olarak belirtmiştir. Testi kolay seviye olarak değerlendiren öğrenciler bu durumu başarılı olmaları; dersi dikkatle dinlemeleri ve çok soru çözmeleri ile ilişkilendirmişlerdir. Testi orta seviye olarak değerlendiren öğrenciler bu durumu ders çalışma ve konu hâkimiyetinin bulunması ile bağdaştırmışlardır. Testi zor olarak değerlendiren öğrenciler ise başarısız olmalarında; konuyu anlamamalarını ve ders çalışmamalarını sebep olarak göstermiştir. Teste yönelik bazı öğrenci ifadeleri alıntı olarak gösterilmektedir. Örneğin Ö$_{8}$ kodlu öğrenci; “Sorular şaşırtıcı geldiği için zorlanıyorum." şeklinde görüşünü açıklarken Ö${ }_{51}$ kodlu öğrenci "Değişkenleri belirleme konusunu anlamadı̆̆ım için ve konu tekrarl yeterince yapmadığım için zorlanıyorum. 'şeklinde görüşünü belirtmiştir. 53 öğrenci arasından üç öğrenci testi çok kolay bulmuş, bir öğrenci testi çok anlaşılır bulduğunu dile getirmiştir. Şekil 2'de öğrenciler için değişkenleri belirlemede etkili olan faktörlere yer verilmiştir.

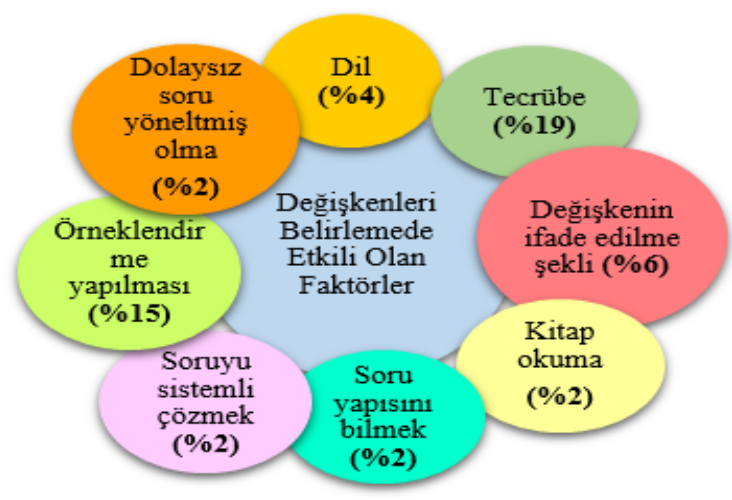

Şekil 2. Değişkenleri belirlemede etkili olan faktörler

Şekil 2'de çalışmada nitel verilerle öğrencilerin gözünden değişken belirlemede etkili olan faktörler sekiz temada toplanmıştır. Öğrenciler değişkenleri belirleyebilmek için konuya dair tecrübelerini en etkili faktör (\%19) olarak 
görmektedir. Test içerisinde örnek bir sorunun ve çözümünün bulunması (\%15) öğrencilerin ikinci önemli bulduğu faktördür. Değişkenin ifade edilme şekli (\% 6) üçüncü sırada etkili olan faktör olarak verilmiştir. Soruların yöneltildiği dil (\%4) dördüncü sırada etkili olan faktör olarak verilmiştir. Öğrencilere soruların dolaysız yöneltilmiş olması, kitap okumaları, soru yapılarını bilmeleri ve soruyu sistemli bir yapıda çözmeleri değişkenleri belirlemede etkili olan faktörler arasındadır ve $\% 2$ orana sahiptir. Soruların çözümüne yönelik bazı öğrenci ifadeleri şu şekildedir. Örneğin $\ddot{O}_{25}$ kodlu öğrenci "Sorulartn kendi özelliğini bilmemiz ve soruyu anlamamız gerektiğini düşünüyorum." şeklinde görüş bildirirken $\mathrm{O}_{47}$ kodlu öğrenci "Soruları düzenli bir şekilde okumamı ve anlamamı gerekir." şeklinde görüş bildirmiştir. Tablo 5'te öğrencilerin değişkenleri belirleme ve kontrol etme testine ilişkin zorlanma ve zorlamama nedenleri verilmiştir.

Tablo 5 .

Öğrencilerin Teste İlişkin Zorlanma/ Zorlanmama Nedenleri

\begin{tabular}{|c|c|c|c|}
\hline Tema & Kodlar & $\mathrm{f}$ & $\%$ \\
\hline \multirow{10}{*}{ 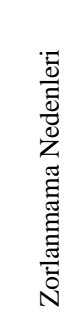 } & Soruların kolay olması & 10 & 19 \\
\hline & Benzer sorular ile daha önce karşılaşma & 6 & 11 \\
\hline & Ders çalışma & 6 & 11 \\
\hline & Konuyu anlama & 6 & 11 \\
\hline & Soruyu anlama & 2 & 4 \\
\hline & Şans & 2 & 4 \\
\hline & Konuyu bilme & 1 & 2 \\
\hline & Konu tekrarı yapma & 1 & 2 \\
\hline & Soruyu hızlı kavrama & 1 & 2 \\
\hline & Zekâ & 1 & 2 \\
\hline \multirow{10}{*}{ 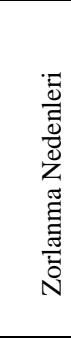 } & Soruyu anlamama & 10 & 19 \\
\hline & Soruların zor olması & 10 & 19 \\
\hline & Konuyu unutma & 10 & 19 \\
\hline & Konuyu anlamama & 8 & 15 \\
\hline & Ders çalışmama & 8 & 15 \\
\hline & Konuyu bilmeme & 7 & 13 \\
\hline & Konuyu dinlememe & 2 & 4 \\
\hline & Heyecanlanma & 2 & 4 \\
\hline & Az soru çözme & 1 & 2 \\
\hline & Çeldiricilerin kuvvetli olması & 1 & 2 \\
\hline
\end{tabular}

Tablo 5'e göre öğrencilerin değişkenleri belirleme ve kontrol etmede zorlanma ya da zorlanmama nedenlerine bakıldığında öğrencilerin bireysel farklılıkları dikkat çekmektedir. Soruların kolay ve zor algılanmasının testte zorlanma ya da zorlanmama durumunu büyük oranda etkilediği görülmektedir. Ders çalışma zorlanma ve zorlanmama nedenlerinde büyük oranda verilen yanttlar arasında olmuştur. Öğrencilerin kendilerini zeki ve şanslı görmesi zorlanmama nedenleri olarak belirtilmiş olup; bazı öğrenciler de soruda istenen sonucu hızlı kavradı̆̆ını düşünmektedir. Heyecanlanma, az soru çözme ve konuları dinlememe, soruların çeldiricilerinin kuvvetli olması ve soruların dolaylı yöneltilmiş olması öğrencileri zorlayan diğer nedenler arasında yer almaktadır. Öğrencilerin başarılı ve başarısız olma nedenleri Tablo 6'da verilmiştir. 
Tablo 6.

Öğrencilerin Teste İlişkin Başarılı/Başarısız Olma Nedenleri

\begin{tabular}{|c|c|c|c|}
\hline Tema & Kodlar & $\mathrm{f}$ & $\%$ \\
\hline \multirow{11}{*}{ 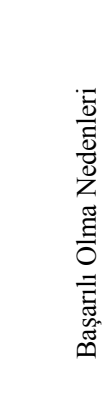 } & Ders çalıma & 19 & 36 \\
\hline & Dersi iyi dinleme & 11 & 21 \\
\hline & Öğretmen faktörü & 10 & 19 \\
\hline & Kitap okuma & 9 & 17 \\
\hline & Konuyu anlama & 6 & 11 \\
\hline & Soru çözme & 4 & 8 \\
\hline & Konuyu bilme & 3 & 6 \\
\hline & Soruların kolay olması & 3 & 6 \\
\hline & Zekâ & 3 & 6 \\
\hline & Şans & 2 & 4 \\
\hline & Konu tekrarı yapma & 2 & 4 \\
\hline \multirow{9}{*}{ 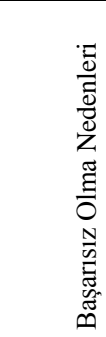 } & Ders çalışmama & 16 & 30 \\
\hline & Soru çözmeme & 8 & 15 \\
\hline & Soruların zor olması & 7 & 13 \\
\hline & Tekrar yapmama & 4 & 8 \\
\hline & Konuyu anlamama & 4 & 8 \\
\hline & Ders dinlememe & 3 & 6 \\
\hline & Konuyu bilmeme & 2 & 4 \\
\hline & Çeldiricilerin kuvvetli olması & 2 & 4 \\
\hline & Dikkatsizlik & 1 & 2 \\
\hline
\end{tabular}

Tablo 6 incelendiğinde, ders çalışma en yüksek başarılı olma nedeni olarak belirlenirken; ders çalışmama en yüksek başarısız olma nedeni olarak ortaya çıkmaktadır. Dersi iyi dinleme öğrencilere göre başarılı olmadaki ikinci ölçüt olmaktadır. Öğretmenlerinin öğrencilerin testteki başarısında etkisi, üçüncü başarılı olma nedeni olarak görülmektedir. Ayrıca öğrencilerin kendilerini zeki ve şanslı görmeleri de başarılı olma durumlarını etkilemektedir. Tablodaki sonuçlara göre kitap okuma başarılı olma nedenlerinden biridir. Soru çözmeme ikinci başarısız olma nedeni olarak görülmektedir. Soruların çözümünde yapılan dikkatsizlik başarısız olma nedeni olarak ifade edilmektedir.

Diğer görüşme sorularına verilen cevaplar sonucunda, sorular daha açık ifade edilirse öğrencilerin \%74'ü soruları daha kolay cevaplandırabileceğini düşünmektedir. Öğrencilerin \%64'ü değişkenleri belirleme ve kontrol etme testinde yer alan soruları daha önce karşılaştığı sorulara benzetmektedir. Bağımlı değişken yerine etkilenen/ölçülen değişken, bağımsız değişken yerine etkileyen/değiştirilen değişken denilirse soruyu öğrencilerin \%50'sinin doğru cevaplandırabileceğini düşünmektedir. Değişkenleri belirleme ve kontrol etme konusunda öğrencilerin $\% 44$ 'ü kendini yeterli bulmaktadır. Ayrıca üç öğrenci değişkenleri belirleme ve kontrol etme konusunu anlayamadığını ve kendisini yetersiz bulduğunu görüşme formunda birkaç kez yansıtmışlardır. Öğrencilerin bazıları hem test için de hem de bu becerinin daha kolay kazandırılabilmesi için önerilerde bulunmuşlardır. Örneğin 
$\ddot{O}_{33}$ kodlu öğrenci "Değişkenleri belirleme konusu daha kolay yöntemlerle ve daha açık anlatılmalı, yoksa ben bir türlü ögrenemiyorum." ifadelerini kullanırken Ö${ }_{50}$ kodlu öğrenci "Test zordu ancak, kitap okumam soruları çözmemdeki hızımı arttırdl." ifadelerini kullanmıștır. Benzer șekilde Ö$_{4}$ kodlu öğrenci "Sorunun üzerine değişken türlerini yazmak soruyu kolay anlayıp cevaplandırmamı sağlayabilir. Ayrıca kitap okumak da bu testi daha kolay hale getirebilirdi." cümleleri ile görüş belirtmiştir. ${ }_{21}$ kodlu öğrenci de "Test soruları bana üniversite sinav soruları gibi geldi. Paragrafların kısalması gerektiğini düşünüyorum." diyerek geliştirilen test için önerilerde bulunmuştur.

Öğrenciler, genel olarak soruların daha açık yazılması gerektiğini ve metinlerin kısaltılması gerektiğini dile getiren önerilerde bulunmuştur. Öğrencilerin ders çalışmalarının, kitap okumalarının, soru yapısını önceden biliyor olmalarının değişkenleri belirleme ve kontrol etme becerisinde önemli unsurlar olduğu söylenebilir. Nicel bulgularda da paralel olarak kitap okumayan öğrencilerin puanlarının daha düşük olduğu tespit edilmiştir. Test ortalaması, madde güçlük ve ayırt etme indeksi verileri öğrencilerin bu ifadeleriyle tutarlılık göstermektedir. Bir diğer ifade ile nicel ve nitel bulguların birbirini desteklediği söylenebilir.

\section{Tartışma, Sonuç ve Öneriler}

$\mathrm{Bu}$ çalışmada değişkenleri belirleme ve kontrol etme becerisini ölçmek amacıyla bir test geliştirme hedeflenmiştir. Elde edilen sonuçlara göre söz konusu amaca ulaşılabildiği ve 8 . sınıf öğrencileri için değişkenleri belirleme ve kontrol etme becerisini ölçmeye yönelik geçerli ve güvenilir bir test geliştirildiği düşünülmektedir. Hem nicel boyutta; öğrencilerin DBVKET sonuçlarına göre yapılan madde analiz sonuçları hem de nitel boyutta; öğrencilerin DBVKET'ne yönelik görüşleri ile bahsedilen testin amacına hizmet ettiği söylenebilir. Bulgularda olduğu gibi bu kısımda da nicel ve nitel sonuçların irdelenmesi ayrı ayrı ele alınmıştır.

Araştırmanın nicel bulgularında testin ortalama güçlüğü 0,50 bulunmuş ve KR-20 güvenirlik katsayısı ise 0,86 olarak hesaplanmıştır. Madde analizleri sonucunda ise test maddelerinin madde güçlük (p) ve madde ayırt etme (rjx) indekslerine bakıldığında, test maddelerinin yeteri kadar iyi olduğu söylenebilir. Testin ortalaması 12,8 olarak hesaplanmıştır. Psikometrik açıdan testteki başarı ortalamasının \%50 civarında olması beklenmektedir (Alkan Dilbaz, Özgelen \& Yanpar Yelken, 2012). $\mathrm{Bu}$ açıdan değerlendirildiğinde 12,8 ortalama ile testin bu beklentiyi karşılar düzeyde olduğu söylenebilir. Bir diğer ifade ile öğrencilerin söz konusu beceride üst düzey performans gösteremediği ve orta düzeyde bir başarı gösterebildiği söylenebilir. Ayrıca testin geneli ve maddelerin güçlük durumu ele alındığında öğrencilerin test sonuçları bağımlı ve bağımsız değişkenleri belirlemede daha az sıkıntı yaşadığını ancak, kontrol edilen değiş̧keni belirlemede, hipotez kurma ve bunları da içinde barındıran karma soruları çözmede daha çok sıkıntı yaşadığını söylemek mümkündür. Alanyazında benzer bir sonuç Durmaz ve Mutlu'nun (2012) çalışmalarında da ifade 
edilmiştir. Fen eğitiminde değişken belirleme becerisinin öğrenciler açısından sıkıntı oluşturan bir beceri olduğu sonucuna ilgili çalışmada ulaşılmışıtır. Ayrıca öğrencilerin değişken belirlemeyi zor bulduğu ve genellikle değişken belirlemeden korktukları ortaya çıkmıştır. Alanyazındaki diğer çalışmalarda da benzer sonuçlar saptanmıştır (Ateş, 2005; Anagün \& Yaşar, 2009; Germann, Aram, Odom \& Burke, 1996; Karamustafaoğlu, 2011; Seetee, Coll, Boonprakob \& Dahsah, 2016). Bu nedenle değişkenleri belirleme ve kontrol etme becerisi bağlamında bu zorluğu ortadan kaldırmak adına konu alanlarına dağıtılmış bir şekilde öğrencilerde korku yaratmadan verilmesinin önemli olduğu düşünülmektedir. Nitekim geliştirilen bu testte farklı konu alanlarına uyarlanan test maddeleri yer almaktadır. Bununla birlikte alanyazında öğrencilerin bilimsel süreç becerilerini ölçerken farklı konular kadar farklı soru tipleri kullanmanın ve bireysel farklılıklara odaklanmanın gerekliliği vurgulanmaktadır (Aktamış \& Şahin Pekmez, 2011; Burns, Okey \& Wise, 1985, Karslı \& Ayas, 2013; Kılınç, 2018; Şardağ \& Kocakülah 2016). Buradan hareketle farklı soru tipleriyle öğrencilerin bireysel farklılıklarına hitap ederek her öğrencinin soruları çözebileceği noktaları ele almasından bahsedilmektedir. Bu araştırmada farklı soru türleri (açık uçlu, çoktan seçmeli vb.) ile oluşturulmuş bir test hazırlanmamıştır. Ancak farklı veri toplama aracılı̆̆ı ile bireysel farklılıkların ve öğrenci görüşlerinin ortaya çıkartılabildiği görülmüştür. Ayrıca bireysel farklılıkları göstermenin yanında nicel ve nitel boyutlardaki paralel ve tezatlıkları ortaya koyması ve bütüncül şekilde süreci göstermesi açısından söz konusu aşamaların hepsinin önemli olduğu söylenebilir. Örneğin nicel bulgularda öğrencilerin değişken belirleme becerisinde çok üst düzey bir performans gösteremediğinden bahsedilebilir. Buna karşın nitel bulgular sonucunda öğrencilerin çoğunun testi kolay bulduğu ve yüksek bir özgüven sergilediği belirlenmiştir. Bu noktada, nicel ve nitel bulgular arasında bir paralellikten bahsetmek güçtür. Bununla birlikte öğrencilerin test seviyesini belirlerken derse olan ilgilerinin belirleyici olduğu söylenebilir. Derse ilgisi olan ve olmayan öğrenci gruplarının her ikisi de testteki performanslarının fen bilimleri dersine ilgilerinden/ilgisizlikten kaynaklandığ ifade etmişlerdir. Bu doğrultuda testi kolay olarak belirten öğrenciler (\%21) başarılı olmalarını dersi dinlemeleri ve çok soru çözmeleri ve kitap okumaları ile ilişkilendirmişlerdir. Buna karşın testi zor olarak değerlendiren öğrenciler (\%19) ise başarısız olmalarını konuyu anlamamalarını ve ders çalışmamalarını ve az soru çözmelerini sebep olarak göstermişlerdir. Nitel bulguları nicel bulgular da bu noktada desteklemektedir. Öğrenci ifadelerinde olduğu gibi testte $\% 27^{\prime}$ lik dilimin testte zorlandığ tespit edilmiştir. Ayrıca görüşmelerde değişkenleri belirlerken etkili olan en önemli faktör değişken belirlemeye ilişkin tecrübeler olarak belirlenmiştir. Ateş ve Bahar (2002) değişkenlerin öğrenciler tarafından kolay anlaşılamamasında kavramsal kargaşaya sebep olabilecek terminolojinin etkisi olduğunu ileri sürmektedir. Bu çalı̧smada da DBVKET maddelerinin yazım dili ve deneyimleri öğrencilerin test başarısını etkileyen önemli faktörler olarak belirlenmiş̧ir. Bununla birlikte başka araştırmacılar tarafindan da bu noktaya vurgu yapılmaktadır. Örneğin Bağcı Kılıç ve diğerleri (2009) çalışmalarında aşağıdaki öneriyi teklif etmektedir. 
"Bă̆ımlı, bağımsız, kontrol edilen değişkenler demek yerine farklı ve özellikle hiç bilmeyenleri dahi günlük anlamlarlyla doğru değişkene yönlendirecek seçenekler denenebilir... Örneğin bă̆ımsız dĕgişken yerine değiştirilen değişken, bă̆ımlı değişken yerine gözlenen değişken, kontrol edilen değişken yerine kontrol altına alınan ifadeleri kullanılabilir",

(Bağcı Kılıç ve diğ, 2009).

$\mathrm{Bu}$ konudaki tek zorlanma sebebi elbette sadece dil faktörü değildir. Değişken belirleme konusunda başka sebepleri de inceleyen birçok çalışma (Anagün \& Yaşar, 2009; Ateş, 2005; Çimen, 2018; Demirdağ, Altun, Fevzioğlu \& Akyıldız 2012; Griffiths \& Thompson, 1993; Irwanto, Rohaeti \& Prodjosantoso, 2018; Laçin Şimşek, 2010; Sermsirikarnjana, Kiddee \& Pupat, 2017) alanyazında bulunmaktadır. Örneğin; Birinci Konur ve Yıldırım'ın (2016) ayrıca Durmaz ve Mutlu'nun (2012) çalışmalarında öğrencilerin üç değişkeni (bağımlı, bağımsız ve sabitlenen) birbiri yerine kullanabildiği ve kavram karmaşası yaşadığ dile getirilmektedir. Bu çalışmada da öğrenciler değişken belirlerken birtakım sorunlarla (dikkatsizlik, konuyu veya soruyu anlamama vb.) karşılaşmışlardır. Değişken kavramlarının ifade edilme şekillerinin değişken belirlemeyi etkileyen bir faktör olduğu araştırmada saptanan bir diğer noktadır. Katılımcılar değişken isimleri değiştiğinde soruyu daha kolay cevaplandırabileceklerini düşünmektedirler. Ancak diğer taraftan değişkenin açık ifadesi öğrenciyi sorudaki değişime yönlendirebilir ve bu da sorunun niteliğinde düşüşe sebep olabilir.

Araştırmanın nitel boyutunda elde edilen sonuçlarda öğrencilerin değişken belirleyebilme başarılarını fen bilimleri öğretmenleriyle ilişkilendirdikleri ortaya çıkmıştır. Öğrencilere göre öğretmenlerinin aktardığı farklı çözüm yolları, sorularda pratiklik ve hız kazanmalarına neden olmaktadır ve öğrenciler öğretmenleri sayesinde değişken belirleyebildiğini düşünmektedir. Bu bağlamda değişken belirleme becerisi öğrencilerin gözünden öğretmen profiliyle bağdaştırılabilmektedir (Akbar \& Rustaman, 2011). Çünkü öğrencilere göre değişkenleri belirleme ve kontrol etme becerisi zaman içerisinde kazandırılabilecek bir beceridir. Öğretmenlerin hemen her konuda bağımlı ve bağımsız değişken kısmına vurgu yapması ile bu becerinin daha kolay kazandırılabileceği düşünülmektedir. Alanyazında, öğrenci ifadelerini destekleyen çalışmalar bulunmaktadır (Artayasa, Susilo, Lestari \& Indriwati, 2017; Demirdağ, Altun, Fevzioğlu \& Akyıldız 2012; Laçin Şimşek, 2010; Maknun, Surtikanti, Munandar \& Subahar, 2012; Pyle, 2008; Temiz, 2020; Zimmerman, 2000). İlgili çalışmalarda öğretmenlerin bilimsel süreç becerilerine sahip olma durumu ve derslerinde yer verme sıklığı ile öğrencilerin aynı becerilere sahip olmasının sıkı bir ilişki içinde olduğu belirtilmektedir. Bir diğer ifade ile öğretmende bu becerilerin olmasının ve öğretmenin derslerinde bu beceriye yer vermesinin direkt olarak öğrencide de bu becerinin gelişmesinde etkili olacağı söylenebilir (Aydoğdu, 2015; Birinci Konur \& Yıldırım, 2016; Çelik, 2013). Araştırma sonuçlarına göre aşağıda belirtilen iki öneri araştırmacılara ve uygulayıcılara önerilebilir. 
> Değişkenleri belirleme ve kontrol etme becerisi daha fazla soruyla test edilebilir ve ilköğretim kademesindeki konu alanlarına uyarlanabilir.

$>$ Değişkenleri belirleme ve kontrol etme becerisini farklı değişkenler açısından ele alacak çalışmalar yürütülebilir. Belirlenen değişkenlerin etki gücüne ve değişkenler açısından ilişkilere odaklanan çalışmalar yürütülebilir.

\section{Çıkar Çatışması ve Etik Kurallar}

Çalışma sürecinde çıkar çatışması ilkelerine ve tüm etik kurallara uyulmuş olup etik kurul izin bilgileri aşağıda paylaşılmaktadır:

Etik değerlendirmeyi yapan kurul adı: Mersin Üniversitesi Etik Kurulu

Etik değerlendirme kararının tarihi: 12.08.2020

Etik değerlendirme belgesi toplantı sayısı: 08

\section{Kaynakça}

Akbar, B., \& Rustaman, N.Y. (2011). PGSD students' ability in science process skills and the development of the scoring instruments. Jurnal Evaluasi Pendidikan, 2(1), 27-39.

Aktamış, H., \& Şahin Pekmez, E. (2011). Fen ve teknoloji dersine yönelik bilimsel süreç becerileri ölçeği geliştirme çalışması. Buca Eğitim Fakültesi Dergisi, 30, 192-205.

Alkan Dilbaz, G., Özgelen, S., \& Yanpar Yelken, T. (2012). Araştırma becerileri testinin (ABT) geliştirilmesi. Abant İzzet Baysal Üniversitesi Eğitim Fakültesi Dergisi, 12(2), 306-332.

Anagün, S.Ş., \& Yaşar, Ş. (2009). Developing scientific process skills at science and technology course in fifth grade students. Elementary Education Online, 8(3), 843-865.

Artayasa, I.P., Susilo, H., Lestari, U., \& Indriwati, S.E. (2017). The effectiveness of the three levels of inquiry in improving teacher training students' science process skills. Journal of Baltic Science Education, 16(6), 908-918.

Ateş, S. (2005). Öğretmen adaylarının değişkenleri belirleme ve kontrol etme yeteneklerinin geliştirilmesi. Gazi Üniversitesi Gazi Eğitim Fakültesi Dergisi, 25(1), 21-39.

Ateş, S., \& Bahar, M. (2002, 16-18 Eylül). Araştırmacı fen öğretimi yaklaşımıyla sınıf öğretmenliği 3. sınıf öğrencilerinin bilimsel yöntem yeteneklerinin geliştirilmesi. [Sözlü bildiri]. V. Ulusal Fen Bilimleri ve Matematik Ĕ̆itimi Kongresi, Ankara, Türkiye.

Atılgan H., Kan, A., \& Doğan, N. (2009). Eğitimde ölçme ve değerlendirme. Anı Yayıncılık.

Ayas, A. (2009). Test geliştirme ve madde analizi. S. Çepni \& S. Akyıldız, (Ed.), Ölçme ve değerlendirme içinde (p. 235-250). Celepler Matbaacilık.

Aydın, Ö., \& Kaptan F. (2014). Fen-teknoloji öğretmen adaylarının eğitiminde argümantasyonun biliş üstü ve mantıksal düşünme becerilerine etkisi ve argümantasyona ilişkin görüşleri. Eğitim Bilimleri Araştırmaları Dergisi, 4(2), 163-188.

Aydınlı, E., Dökme, İ., Ünlü, Z.K., Öztürk, N., Demir, R., \& Benli, E. (2011). Turkish elementary school students' performance on integrated science process skills. Procedia Social and Behavioral Sciences, 15, 3469-3475.

Aydoğdu, B. (2006). İlköğretim fen ve teknoloji dersinde bilimsel süreç becerilerini etkileyen değişkenlerin belirlenmesi (Tez No. 189837) [Doktora tezi, Dokuz Eylül Üniversitesiİzmir]. Yükseköğretim Kurulu Başkanlığı Tez Merkezi. 
Aydoğdu, B. (2015). The investigation of science process skills of science teachers in terms of some variables. Educational Research and Reviews, 10(5), 582-594.

Aydoğdu, B., Tatar, N., Yıldız, E., \& Buldur, S. (2012). İlköğretim öğrencilerine yönelik bilimsel süreç becerileri ölçeğinin geliştirilmesi. Kuramsal Eğitimbilim Dergisi, 5(3), 292311.

Aydoğdu, B., \& Ergin, Ö. (2012). Fen ve teknoloji dersi "kuvvet ve hareket” ünitesine yönelik bilimsel süreç becerileri ölçeğinin geliştirilmesi. E-international Journal of Educational Research, 3(1), 49-52.

Bailer, J., Ramig, J., \& Ramsey, J.M. (1995). Teaching science process skills (Good Apple science resource book for grades 6-8). Good Apple.

Bağcı Kılıç, G., Yardımcı, E., \& Metin, D. (2009). Fen öğretiminde değişkenler nasıl adlandırllabilir?. Abant İzzet Baysal Üniversitesi Dergisi, 9(2), 13-26.

Birinci Konur, K., \& Y1ldırım, N. (2016). Pre-service science and primary school teachers' identification of scientific process skills. Universal Journal of Educational Research 4(6), 1273-1281.

Burns, J.C., Okey, J.R., \& Wise, K.C. (1985). Development of an integrated process skill test: TIPSII. Journal of Research in Science Teaching, 22(2), 169-177.

Büyüköztürk, Ş. (2010). Veri analizi el kitabı. Pegem Akademi.

Carin, A.A. (1993). Teaching science through discovery. Macmillan Publishing Company.

Celep, A., \& Bacanak, A. (2013). Yüksek lisans yapan öğretmenlerin bilimsel süreç becerileri ve kazandırılması hakkındaki görüşleri. Türk Fen Eğitimi Dergisi, 10(1), 56-78.

Creswell, J.W., \& Plano Clark, V. (2018). Designing and conducting mixed methods research. SAGE Publications.

Çelik, P. (2013). Probleme dayalı öğrenmenin öğretmen adaylarının fizik dersi başarısı, ögrenme yaklaşımları ve bilimsel süreç becerileri üzerindeki etkisi (Tez No. 342322) [Doktora tezi, Dokuz Eylül Üniversitesi-İzmir]. Yükseköğretim Kurulu Başkanlığı Tez Merkezi.

Çepni, S., Ayas, A., Johnson D., \& Turgut M.F. (1997). Fizik öğretimi. Ankara: YÖK/Dünya Bankası Milli Eğitimi Geliştirme Projesi, Hizmet Öncesi Öğretmen Eğitimi.

Çimen, R. (2018). TIMSS soruları ile fen bilimleri öğretmen adaylarının mantıksal düşünme (akıl yürütme) becerilerinin belirlenmesi (Tez No. 531071) [Yüksek lisans tezi, Mersin Üniversitesi-Mersin]. Yükseköğretim Kurulu Başkanlığı Tez Merkezi.

Demirdağ, B., Altun, E., Fevzioğlu, B., \& Akyıldız, M. (2012). Ortaöğretim öğrencilerine yönelik bilimsel süreç becerileri testi geliştirilmesi: Geçerlik ve güvenirlik çalışması. Kuram ve Uygulamada Eğitim Bilimleri Dergisi, 12(3), 1887-1906.

Durmaz, H., \& Mutlu, S. (2012). 7. sınıf öğrencilerinin bilimsel süreç becerilerini geliştirmeye yönelik bir çalı̧̧ma örneği. Necatibey Eğitim Fakültesi Elektronik Fen ve Matematik Ĕ̈itimi Dergisi, 6(1), 124-150.

Geban, Ö., Aşkar, P., \& Özkan, İ. (1992). Effects of computer simulations and problem-solving approaches on high school students. The Journal of Educational Research, 86(1), 5-10.

Germann, P.J. (1994). Testing a model of science process skills acquisition: An interaction with parents' education, preferred language, gender, science attitude, cognitive development, 
academic ability, and biology knowledge. Journal of Research in Science Teaching, 31(7), 749-783.

Germann, P.J., Aram, R., Odom, A.L., \& Burke, G. (1996). Student performance on asking questions, identifying variables, and formulating hypotheses. School Science and Mathematics, 96(4), 192-201.

Griffiths, A.K., \& Thompson, J. (1993). Secondary school students' understandings of scientific process: An Interview Study. Research in Science \& Technological Education, 11, 15-26.

Gönen, S., Kocakaya, S., \& Kocakaya, F. (2011). Dinamik konusunda geçerliliği ve güvenilirliği sağlanmış bir başarı testi geliştirme çalışması. Yüzüncü Yıl Üniversitesi Eğitim Fakültesi Dergisi, 8(1), 40-57.

Harlen, W. (1999). Purposes and procedures for assessing science process skills. Assessment in Education: Principles, Policy \& Practice, 6(1), 129-144.

Irwanto, Rohaeti, E., \& Prodjosantoso, A.K. (2018). Undergraduate students' science process skills in terms of some variables: A perspective from Indonesia. Journal of Baltic Science Education, 17(5), 751-764.

Jurecki, K., \& Wander, M. (2012). Science literacy, critical thinking and scientific literature: Guidelines for evaluating scientific literature in the classroom. Journal of Geoscience Education, 60(2), 100-105. doi:10.5408/11-221.1

Karamustafaoğlu, S. (2011). Improving the science process skills ability of science student teachers using I diagrams. Eurasian Journal of Physic and Chemistry Education, 3(1), 2638.

Karslı, F., \& Ayas, A. (2013). Fen ve teknoloji dersi öğretmen adaylarının bilimsel süreç becerilerinin ölçülmesine ilişkin bir test geliştirme çalışması. Türk Fen Eğitimi Dergisi, 10(2), 66-84.

Kılınç, H. S. (2018). Fen bilgisi öğretmenlerinin ve öğretmen adaylarının bilimsel süreç becerilerine sahip olma düzeylerinin incelenmesi: Ölçek geliştirme ve uygulama çalışması (Tez No. 517649) [Yüksek lisans tezi,, Mersin Üniversitesi-Mersin]. Yükseköğretim Kurulu Başkanlığı Tez Merkezi.

Kilmen, S. (2014). Madde analizi, madde seçimi ve yorumlanması. N. Demirtaşlı, (Ed.), Ĕ̆itimde ölçme ve değerlendirme içinde (p. 373-395). Edge Akademi.

Laçin Şimşek, C. (2010). Sınıf öğretmeni adaylarının fen ve teknoloji ders kitaplarındaki deneyleri bilimsel süreç becerileri açısından analiz edebilme yeterlilikleri. İlköğretim Online, 9(2), 433-445.

Lakin, S., \& Wellington, J. (1994). Who will teach the 'nature of science'?: teachers' views of science and their implications for science education. International Journal of Science education, 16(2), 175-190.

Lati, W., Supasorn, S., \& Promarak, V. (2012). Enhancement of learning achievement and integrated science process skills using science inquiry learning activities of chemical reaction rates. Procedia - Social and Behavioral Sciences, 46, 4471-4475.

Maknun, D., Surtikanti, R.R.A.K., Munandar, A., \& Subahar, T. S. (2012). Essential skills and laboratorium motoric competencies of biology student teachers in animal ecology practicum. Jurnal Pendidikan Indonesia, 1(2), 141-148. 
Martin, D.J. (1997). Elementary science methods: a constructivist approach. Delmar Publishers.

Milli Eğitim Bakanlığı. (2018). Fen bilimleri dersi (3, 4, 5, 6, 7 ve 8. sinıflar) öğretim programı. Milli Eğitim Bakanlığı Yayınları.

Meriç, G., \& Karatay, R. (2014). Ortaokul 7 ve 8. sınıf öğrencilerinin bilimsel süreç becerilerinin incelenmesi. Tarih Okulu Dergisi, 7(18), 653-669.

Miles, M.B., \& Huberman, A. M. (1994). Qualitative data analysis: An expanded Sourcebook. $\left(2^{\text {nd }}\right.$ ed $)$. Sage

Mohd Saat, R. (2004). The acquisition of integrated science process skills in a web-based learning environment. Research in Science \& Technological Education, 22(1), 23-40.

Morgan, D.L. (1998). Practical strategies for combining qualitative and quantitative methods: Applications to health research. Qualitative Health Research, 8(3), 362-376.

Organisation for Economic Co-operation and Development (OECD), (2007), Assessing scientific, reading and mathematical literacy: a framework for PISA 2006, retrieved from http://www.oecd-ilibrary.org/education/assessingscientific-reading-and-mathematicalliteracy_9789264026407-en.

Öç, U. (2019). Argümantasyona dayalı fen laboratuvarı uygulamalarının bilimsel süreç becerileri, laboratuvara yönelik tutum ve yaratıcılı̆̆a etkisi (Tez No. 546606) [Yüksek lisans tezi, Cumhuriyet Üniversitesi-Sivas]. Yükseköğretim Kurulu Başkanlığı Tez Merkezi.

Özçelik, D.A. (2010). Okullarda ölçme ve değerlendirme: Öğretmen el kitabı. Pegem Akademi.

Öztürk, N., Tezel, O., \& Acat, M.B. (2010). Science process skills levels of primary school seventh grade students in science and technology lesson. Journal of Turkish Science Education, 7(3), 15-28.

Pilten, P. (2008). Matematiksel muhakemeyi değerlendirme ölçeği: Ölçek geliştirme, güvenirlik ve geçerlik çalışması. Selçuk Üniversitesi Ahmet Keleşoğlu Eğitim Fakültesi Dergisi, 25, 297-316.

Plano Clark, V., \& Ivankova, N. (2016). Mixed methods research: A guide to the field. Sage.

Prayitno, B.A., Corebima, D., Susilo, H., Zubaidah, S., \& Ramli, M. (2017). Closing the science process skills gap between students with high and low level academic achievement. Journal of Baltic Science Education, 16(2), 266-277.

Pyle, E.J. (2008). A model of inquiry for teaching earth science. Electronic Journal of Science Education, 12(2), 3-21.

Rubin, R.L., \& Norman, J.T. (1992). Systematic modeling versus the learning cycle: Comparative effects on integrated science process skill achievement. Journal of Research in Science Teaching, 29(7), 715-727.

Seetee, N., Coll, R.K., Boonprakob, M., \& Dahsah, C. (2016). Exploring integrated science process skills in chemistry of high school students. Veridian E-Journal, 9(4), 247-259.

Serin, G. (2009). Probleme dayalı öğrenme öğretiminin 7. sınıf öğrencilerinin fen başarısına, fen tutumlarına ve bilimsel süreç becerilerine etkisi (Tez No. 238628) [Doktora tezi, Orta Doğu Teknik Üniversitesi- Ankara). Yükseköğretim Kurulu Başkanlığı Tez Merkezi. 
Sermsirikarnjana, P., Kiddee, K., \& Pupat, P. (2017). An integrated science process skills needs assessment analysis for Thai vocational students and teachers. Asia-Pacific Forum on Science Learning and Teaching, 18(2), 1-25.

Suryanti S., İbrahim M., \& Lede N.S. (2018), Process skills approach to develop primary students' scientific literacy: a case study with low achieving students on water cycle, IOP Conference Series: Materials Science and Engineering, 296, 12-30, doi:10.1088/1757899X/296/1/012030.

Şahintepe, S. (2018). Sorgulamaya dayalı öğrenme yaklaşımının öğrencilerin üstbiliş farkındalıklarına ve bilimsel süreç becerilerine etkisi (Tez No. 518444) [Yüksek lisans tezi, Afyon Kocatepe Üniversitesi- Afyon). Yükseköğretim Kurulu Başkanlığı Tez Merkezi.

Şardağ, M., \& Kocakülah, A. (2016). Sekizinci sınıf öğrencilerine yönelik bir bilimsel süreç becerileri testi geliştirme çalışması. Sakarya Üniversitesi Eğitim Fakültesi Dergisi, 31, 132.

Tekin, H. (2010). Ĕgitimde ölçme ve değerlendirme. Yargı Yayınevi

Temiz, B.K., \& Tan, M. (2007). Değişkenleri değiştirme ve kontrol etme becerilerinin ölçülmesi. Gazi Eğitim Fakültesi Dergisi, 27(3), 151-174.

Temiz, B.K. (2020). Assessing skills of identifying variables and formulating hypotheses using scenario-based multiple-choice questions. International Journal of Assessment Tools in Education, 7(1), 1-17.

Tosun, C. (2019). Scientific process skills test development within the topic "Matter and its Nature" and the predictive effect of different variables on $7^{\text {th }}$ and $8^{\text {th }}$ grade students' scientific process skill levels. Chemistry Education Research and Practice, 20, 160-174. doi: 10.1039/C8RP00071A

Turan M.M. (2014). İlköğretim öğrencileri için bilimsel süreç değerlendirme testinin uyarlanması geçerlik ve güvenirliğinin incelenmesi (Tez No. 394642) [Yüksek lisans tezi, Zirve Üniversitesi-Gaziantep]. Yükseköğretim Kurulu Başkanlığı Tez Merkezi.

Turgut, M.F., \& Baykul, Y. (2010). Eğitimde ölçme ve değerlendirme. PegemA Yayıncılık.

Üstün, U., Özdemir, E., Cansız, M., \& Cansız, N. (2019). Türkiye'deki öğrencilerin fen okuryazarlığını etkileyen faktörler nelerdir? PISA 2015 verisine dayalı bir hiyerarşik doğrusal modelleme çalışması. Hacettepe Üniversitesi Eğitim Fakültesi Dergisi. Erken Görünüm. doi: 10.16986/HUJE.2019050786.

Yeany, R.H., Yap, K.C., \& Padilla, M.J. (1986). Analyzing hierarchical relationships among modes of cognitive reasoning and integrated science process skills. Journal of Research in Science Teaching, 23(4), 277-291.

Yıldırım, A., \& Şimşek, H. (2018). Sosyal bilimlerde nitel araştırma yöntemleri. Seçkin Yayıncilik.

Zimmerman, C. (2000). The development of scientific reasoning skills. Developmental Review, 20, 99-149.

\section{Soru Geliştirmede Yararlanılan Kaynaklar}

Burns, J.C., Okey, J.R., \& Wise, K.C. (1985). Development of an integrated process skill test: TIPSII. Journal of Research in Science Teaching, 22(2), 169-177. 
Eba-Eğitim Bilişim Ağı, $\quad$ T.C. Milli Eğitim Bakanlığı, https://www.eba.gov.tr/video/izle/94845c2e1c3037d56425b85271438d52d3d8d2d09c001.

Kılınç, H.S. (2018). Fen bilgisi öğretmenlerinin ve öğretmen adaylarının bilimsel süreç becerilerine sahip olma düzeylerinin incelenmesi: Ölçek geliştirme ve uygulama çalışması. (Yüksek Lisans Tezi). Mersin, Mersin Üniversitesi.

TIMMS (2007). TIMMS \& PIRLS Intarnational Study Center. International Association for the Evaluation of Educational Achievent (IEA).

https://pisavetimsssinavlari.wordpress.com/2012/01/22/timss-2007-sorulari.

TIMMS (2003). TIMMS \& PRLS Intarnational Study Center. International Association for the Evaluation of Educational Achievent (IEA).

https://pisavetimsssinavlari.wordpress.com/2012/01/22/timss-2003-sorulari.

\section{Extended Abstract}

Contemporary science teaching attaches importance to scientific process skills and the science curriculum defines scientific process skills as a learning domain (MoNE, 2018). The main purpose of science education is to ensure that following the development of scientific process skills, students can apply them in different environments and develop scientific explanations and arguments from the data produced by these processes (Aydin and Kaptan, 2014). There are studies in the literature that classify scientific process skills into two categories as basic and integrated science process skills (Bailer, Ramig and Ramsey, 1995; Burns, Okey and Wise, 1985; Germann, 1994; Lakin and Wellington, 1994; Rubin and Norman, 1992; Mohd Saat, 2004; Yeany, Yap and Padilla, 1986). Some scientific process skills require higher level competences one of which is the skill of identifying and controlling variables. A variable is a feature that differs from one state to another, from one observation to another observation (Büyüköztürk, 2010).

This study aimed to develop a test to measure $8^{\text {th }}$ graders' ability to identify and control variables from scientific process skills; namely "The Test for Identifying and Controlling Variables-TICV" which includes multiple choice items. In the study explanatory sequential design was used that it one of the mixed research designs. The main implementation of the test was conducted with $5488^{\text {th }}$ graders in Mersin Province. During the implementation, 54 students were interviewed. During the test development process, the studies relevant to "identifying variables" were examined and a pool of 30 items was built by consulting 4 experts to ensure content validity. Implementation was carried out in three phases as preliminary, pilot and actual implementation. The preliminary implementation was conducted with $218^{\text {th }}$ graders in a secondary school in Mersin. The test, which was finalized with the help of item analysis, included 27 multiple-choice items. After the results obtained from the preliminary implementation, the number of items was reduced to 24 . After the test, 8 students were interviewed through semi-structured interview to receive their views on the test. Following the preliminary implementation, pilot study was conducted with $4378^{\text {th }}$ graders in Mersin Province. As a result of item analysis, 3 questions in the test 
were revised and the number of items remained as 24. During the pilot implementation, 38 students were interviewed. The factors that determined students' test levels and the reasons for finding the test difficult or easy were determined. The KR-20 value of the pilot implementation was found to be 0.86. As a result of the interviews conducted after the pilot implementation, it was found that the students who were interested in science classes and who read books found the test understandable whereas the students who professed disinterest in science classes and who did not regularly read books did not find the test understandable.

Results showed that students had low levels skills in identifying and controlling variables. In the literature, a similar finding was obtained in the study conducted by Durmaz and Mutlu (2012). The skill of identifying and controlling variables in science education is an issue that poses a problem for students and teachers. The study concluded that students found it difficult to identify variables and they were generally apprehensive in doing so. Similar results were found in the studies in the literature (Ateş, 2005; Ateş and Bahar, 2002; Griffiths and Thompson, 1993; Germann, Aram, Odom and Burke, 1996).

Based on students' test results, it was concluded that students had little problem in identifying dependent and independent variables, but they had issues in identifying the controlled variable, forming hypotheses and solving complex problems that included the previously cited elements. According to item analysis, it can be argued that test items were good enough when item difficulty (p) and item discrimination index (r) indexes were taken into consideration. The average difficulty of the test which consisted of 24 items was calculated to be 0.50 and the KR-20 reliability coefficient was 0.86 . It was determined that most of the students found the test easy. It can be argued that the students' interest in science classes was the determinant factor in their test levels. In this context, based on item analysis results, it can be argued that the test is a viable test that can serve its purpose.

This study found that experience was the most important factor in identifying variables. The students encountered some problems (carelessness, not understanding the subject or the question, etc.) while identifying variables. Another finding obtained by this study concluded that the manner through which the concept of variable was expressed affected identification of variables. It was observed that students associated their achievement in identifying variables with science teachers. The skill of identifying and controlling variables can be gained over time. It was found that students did not consider themselves sufficient in terms of many factors that could be effective in identifying variables. The results of item analysis for The Test for Identifying and Controlling Variables showed the test to be a viable and applicable test. The results of student interviews presented that students associated their status in identifying variables with experience while they associated their achievement in the test with the amount of studying they accomplish.

\section{EK 1: Değişkenleri Belirleme ve Kontrol Etme Testi (DBVKET)}


Soru 1: Hasan ve Ahmet bir parkta oynamaktadırlar. Ahmet, oyun sahasindaki kaydıraktan mermer parçasını aşağıya doğru bırakır. Hasan, eğer mermer parçası daha yüksek kaydıraktan aşağı yuvarlanırsa daha hızlı hareket edebileceğini Ahmet'e söyler. Öğrencilerin tartışması, aşağıdaki araştırma sorusuna yol açmaktadır. Tartışmaya şahit olan Hasan ve Ahmet'in arkadaşları yorumlarda bulunmuşlardır. Öğrencilerden hangisi yanlış yorum yapmıştır?

Araştırma sorusu: Bir mermer parçası, bir rampanın kaydırak yüksekliği değiştiği zaman kaymaya bırakıldığında hızı ne olur?
A) Nazlı: Araştırmanın hipotezi 'Rampanın yüksekliği arttıkça mermer parçasının hızı artar.' olabilir.
B) Burak: Mermer parçasının hızı bağımlı değişkendir.
C) Selim: Kaydırak yüzeyi bağımsız değişkendir.
D) Elif: Kaydırak yüzeyi, mermer parçasının bırakılma noktası kontrol edilen değişkenlerdir

Soru 2: Melisa, karlı bir günde bir kamyonun yol üzerine tuz serpelediğini fark eder. Kamyon, Melisa'nın evini geçtikten sonra Melisa kamyonun geçtiği yola gidip, gözlem yapar. Melisa gözleminden, yürüttüğü deney için aşağıdaki araştırma sorusunu oluşturmuştur.

Araştırma Sorusu: Eğer buza tuz eklenirse nasıl bir durum gözlenir? Tabloda hangi satırda hata vardır?

\begin{tabular}{|l|l|l|}
\hline A) & Hipotez & Buza tuz eklenirse buz daha çabuk erir. \\
\hline B) & Bağımlı Değişken & Eriyen buzun miktarı \\
\hline C) & Bağımsı Değişken & Tuz eklenmesi \\
\hline D) & Kontrol Edilen Değişken & Buzun erime süresi \\
\hline
\end{tabular}

\section{Soru 3:}

Kum, toprak ve su

Bir öğrenci, bitkilerin sağlıklı büyümesi için toprakta kum bulunması gerektiğini düşünmektedir. Bu düşüncesini test etmek için aynı tür ve özellikte iki saksı bitkisi kullanır. Saksı bitkilerinden birini yukarıdaki gibi hazırlamıştır. Buna göre, ikinci saksı bitkisi aşağıdakilerden hangisi gibi hazırlanmalıdır? (Deneylerde kullanılan kum, su ve toprağın miktarı ve özellikleri ile ortam sıcaklığı özdeş tutulacaktır.) 
A)

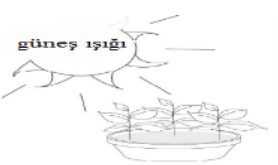

Kum ve su

B)

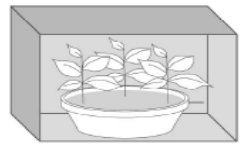

Karanlık dolapta kum, toprak ve su

C)

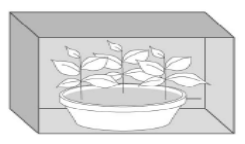

Karanlık dolapta toprak ve su

D)

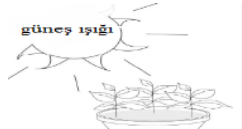

Toprak ve su

Soru 4: Aşağıda basit elektrik devresi sembolize edilmiştir. Basit elektrik devresinde hipotezler oluşturulacak ve yapılan değişikliklerle hipotezler sınanacaktır. Yapılan değişikliğe göre değişkenler belirtilmiştir. Tabloda hangi satırda hata vardır?

\begin{tabular}{|l|l|l|l|l|}
\hline Yapılan & $\begin{array}{l}\text { Kontrollü } \\
\text { Değişiklik } \\
\text { Değişken }\end{array}$ & $\begin{array}{l}\text { Bağımsız } \\
\text { Değişken }\end{array}$ & Bağımlı Değişken \\
\hline A & $\begin{array}{l}\text { Ampul sayısının } \\
\text { değiştirilmesi }\end{array}$ & Pil sayısı & Ampul sayısı & Ampulün parlaklığı \\
\hline B & $\begin{array}{l}\text { Bağlantı } \\
\text { kablosunun } \\
\text { kısaltılması }\end{array}$ & Ampul sayısı & $\begin{array}{l}\text { Bağlantı } \\
\text { kablosunun } \\
\text { çeşidi }\end{array}$ & $\begin{array}{l}\text { Ampulün sayısının } \\
\text { değiştirilmesi }\end{array}$ \\
\hline C & $\begin{array}{l}\text { Bağlantı } \\
\text { kablosunun } \\
\text { uzunluğunun } \\
\text { arttırılması }\end{array}$ & Pil sayısı & $\begin{array}{l}\text { Bağlantı } \\
\text { kablosunun } \\
\text { uzunluğu }\end{array}$ & Ampulün parlaklığı \\
\hline D & $\begin{array}{l}\text { Pil sayısının } \\
\text { değiştirilmesi }\end{array}$ & Ampul sayısı & Pil sayısı & Ampulün parlaklığ1 \\
\hline
\end{tabular}


Soru 5: Üç özdeş mum şekilde gösterildiği gibi kavanozlara yerleştirilir ve aynı anda yakılır. Y ve Z kavanozlarının kapağı kapatılırken, X kavanozunun kapağı ise açık bırakılır. Bu deneyin bağımlı değişkeni hangisidir?

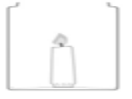

$X$

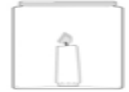

$Y$

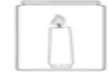

$Z$
A) Mumun büyüklüğü
B) Mumun erime hizı
C) Mumun erime süresi
D) Kabın büyüklüğü

Soru 6: Bir çiftçi yetiştirdiği domates fidanlarına $X$ türünde bir böceğin zarar verdiğini fark ediyor ve böceklerin domates fidanlarına verdiği zarardan kurtulmak istiyor. Bir arkadaşı zirai ilaç olarak 'böcek kovucu pudra' kullanmasını tavsiye ederken, ilçe ziraat mühendisi 'domates koruyucu sprey' tavsiye ediyor. Çiftçi iki ilacı da satın alıyor. Bahçesindeki fidanlardan üç tanesini böcek kovucu pudra ile diğer üç tanesini de domates koruyucu sprey ile ilaçlıyor. Çiftçi ilaçladığı domates fidanlarının üzerlerindeki ölmüş olan X türü böcekleri sayarak deneyi için veri topluyor. Deneye göre hangisi doğru verilmiştir?

A) Bağımlı Değişken: Zirai ilaç türü

B) Bağımsız Değişken: Ölmüş böcek sayısı (X)

C) Kontrol Edilen Değişken: Domates fidanı türü

D) Hipotez: Aynı domates fidanlarına birden fazla zirai ilaç kullanılırsa böcek sayısı değişir.

Soru 7:

\begin{tabular}{lr}
$s$ & $p$ \\
\hline 0 & 0 \\
1 & 5 \\
2 & 10 \\
3 & 15
\end{tabular}

Matematik sınavında doğru cevapladığınız her soru için 5 puan kazanıyorsunuz. Yukarıdaki tabloda $s$ doğru cevapladığınız soru sayısını, $p$ ise toplam puanınızı yani sınav sonucunuzu veriyor. Bu iki değişken arasındaki ilişki ise aşağıdaki eşitlik ile ifade edilmiştir.

$$
p=5 s
$$

Aşağıda bazı ifadeler verilmiştir. Bunların sırasıyla hangi değişken türüne ait olduğunu bulup, işaretleyiniz.

Alınan puan $(p)$ - doğru cevap sayısı $(s)$ - her soruya verilen puan (5 puanı) 
A) Bağımlı değişken - bağımsız değişken- kontrol değişkeni

B) Bağımsız değişken - bağımlı değişken- kontrol değişkeni

C) Bağımsız değişken - kontrol değişkeni- bağımlı değişken

D) Kontrol değişkeni - bağımlı değişken- bağımsız değişken

Soru 8: Şekillerde, Osman'ın iki farklı boyutta tekerleğe ve farklı sayıda eşit kütleli bloğa sahip arabalarla gerçekleştirdiği denemeler gösterilmektedir. Tüm denemelerde arabaları, aynı rampaları kullanarak değişik yüksekliklerden bırakmıştır. Test etmek istediği düşünce şudur: “ Arabanın bırakıldığı yükseklik artarsa, araba zemine daha büyük hızla ulaşır.” Buna göre hangi üç denemeyi karşılaştırmalıdır?

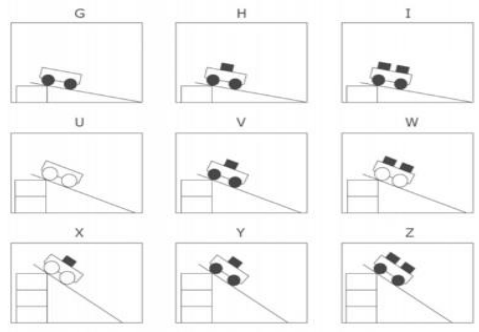
A) $\mathrm{G}, \mathrm{H}$ ve I
B) $\mathrm{I}, \mathrm{W}$ ve $\mathrm{Z}$
C) I, V ve $X$
D) $\mathrm{H}, \mathrm{V}$ ve $\mathrm{Y}$

(9-12 arast sorulart metne göre cevaplayını.)

Beslenme uzmanları, 65 yaşını aşmış kişiler arasından rastgele seçilmiş olan 100 kişilik bir gözlem grubunun aldı̆̆g günlük C-vitamini oranını değiştirebilirler. Bu gözlem grubunun yarısı, 15 yıl gibi uzun bir dönemde yüksek dozda (2000mg) Cvitamini tableti almaları ve diğer yarısının da $C$ vitamini almamaları sağlanmıştır. Yüksek C-vitamini dozu alanların gribe yakalanma sıklı̆̆ ve $C$-vitamini almayanların gribe yakalanma sıklı̆̆ arasındaki ilişkiyi incelemişler ve yüksek dozda C vitamini tableti kullanan kişilerin gribe yakalanma sıklı̆̆ının, $C$-vitamini almayan kişilere göre daha az olduğu ortaya çıkmıştır.

Soru 9: Bu deneyde deney sonuçlarının doğruladığı hipotez hangisidir?

A) Vücuda alınan $\mathrm{C}$ vitamini miktarı artarsa gribe yakalanma oranı artar.

B) Vücuda alınan C vitamini miktarı artarsa gribe yakalanma sıklığı azalır.

C) Vücuda alınan C vitamini miktarı azalırsa gribe yakalanma sıklığı azalır.

D) Vücuda alınan $\mathrm{C}$ vitamini miktarı gribe yakalanma oranını etkilemez. 
Soru 10: Bu araştırmada sizce bağımlı değişken hangisidir?
A) Alınan $\mathrm{C}$ vitamini miktarı
B) C vitamini alma süresi
C) C vitaminini toz halinde almaları
D) Gribe yakalanma sıklığ 1

Soru 11: Sizce araştırmanın kontrol değişkeni hangisidir?
A) C vitamini almaları
B) Gribe yakalanma sıklığ
C) Kişilerin 65 yaş üstü kişilerden seçilmesi
D) C vitaminini toz halinde almaları

Soru 12: Sizce araştırmadaki bağımsız değişken hangisidir?
A) Gribe yakalanma sıklı̆̆
B) Alınan C vitamini miktarı
C) Kişilerin 65 yaş üstü kişilerden seçilmesi
D) C vitamini alma süresi

\section{(13-16 arası soruları metne göre cevaplayını.)}

Topră̆a karıştırılan yaprakların domates üretimine etkisi araştırılmaktadır. Araştırmada dört saksıya aynı miktarda ve tipte toprak konulmuştur. Fakat birinci saksıdaki toprağa $15 \mathrm{~kg}$, ikinciye $10 \mathrm{~kg}$, üçüncüye ise $5 \mathrm{~kg}$ çürümüş yaprak karıştırılmıştır. Dördüncü saksıdaki toprağa çürümüş yaprak karıştırılmamıştır. Daha sonra bu saksılara domates ekilmiştir. Bütün saksılar güneşe konmuş ve aynı miktarda sulanmıştır. Her saksıdan elde edilen domates tartılmış ve kaydedilmiştir.

Soru 13: $\mathrm{Bu}$ araştırmada sizce sınanan hipotez hangisidir?
A) Bitkiler güneşten ne kadar çok 1şık alırlarsa, o kadar fazla domates verirler.
B) Saksılar ne kadar büyük olursa, karıştırılan yaprak miktarı o kadar fazla olur.
C) Saksılar ne kadar çok sulanırsa, içlerindeki yapraklar o kadar çabuk çürür.
D) Toprağa ne kadar çok çürük yaprak karıştırılırsa, o kadar fazla domates elde edilir.

Soru 14: Sizce bu araştırmada kontrol edilen değişken hangisidir?
A) Her saksıdan elde edilen domates miktarı
B) Saksılara karıştırılan yaprak miktarı
C) Yaprak çeşidi
D) Saksıların sulanma miktarı

Soru 15: Sizce araştırmada bağımlı değişken hangisidir?
A) Her saksıdan elde edilen domates miktarı
B) Saksılara karıştırılan yaprak miktarı
C) Saksılardaki toprak miktarı
D) Saksıların sulanma miktarı 
Soru 16: Sizce araştırmada bağımsız değişken hangisidir?

A) Her saksıdan elde edilen domates miktarı

B) Saksılara karıştırılan yaprak miktarı

C) Saksılardaki toprak miktarı

D) Çürümüş yaprak karıştırılan saksı sayısı

(17-20 arası soruları metne göre cevaplandırınız.)

Fırat'ın bir paket içinde genetik yapısı aynı olan bezelye tohumlarl vardır. Bunlar bir tür uzun gövdeli bezelye bitkisi tohumudur. Firat bu bezelye tohumlarından dört tanesini Şekil 1'de gösterilen koşullardaki bir kaba, diğer dört tanesini de Şekil 2'de gösterilen koşullardaki bir kaba eker. Tohumları her gün sular. Bezelye bitkilerinin büyüme süreleri değişiklik göstermiştir. Buna göre;

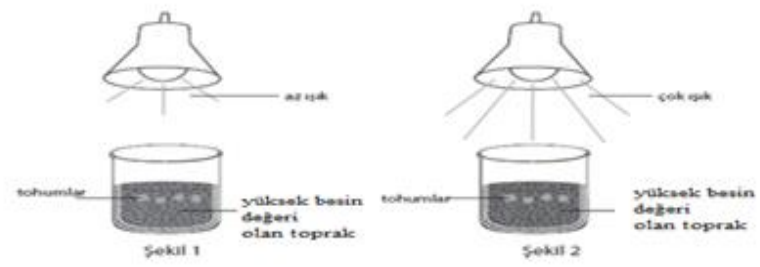

Soru 17: Sizce araştırmanın kontrol değişkeni hangisi olamaz?
A) Işık miktarı
B) Sulama miktar1
C) Tohum cinsi
D) Tohum büyüklüğü

Soru 18: Sizce araştırmada bağımlı değişken hangisidir?
A) Bezelye bitkisinin büyüme süresi
B) Besin değeri
C) Sulama zamanı
D) Işık miktarı

Soru 19: Bu araştırmada sizce sınanan hipotez hangisidir?
A) Maruz bırakılan ışık miktarı bitki tohumlarının büyüme sürelerini etkiler.
B) Işı miktarı artarsa bitkinin büyüme miktarı artar
C) Işık miktarı azalırsa bitkinin büyüme miktarı azalır.
D) Besin değerinin düşük veya yüksek olması bitki tohumlarının büyüme sürelerini etkiler.


Soru 20: Sizce araştırmada bağımsız değişken hangisidir?
A) Bezelye bitkisinin büyüme süresi
B) Besin değeri
C) Ișı miktarı
D) Sulama miktarı

(21-24 numaralı soruları metne göre cevaplayını.)

8-B sınıfı Asitler ve Bazlar konusunda turnusol kâğıdıyla deney yapmaktadırlar. Eşit büyüklükte olan turnusol kağıtlarına madde sürülüp, kağıttaki etkisine göre asit veya baz olduklarına karar vereceklerdir. Limon sürülünce turnusol kâğıdının kırmızı renk aldığını, diş macunu sürülünce turnusol kâğıdının mavi renk aldığııı gözlemlemişlerdir. Sinem Öğretmen deney sonuçlarından sonra öğrencilerden değişkenleri belirlemelerini istemiştir.

Soru 21: Bu araştırmada deney sonuçlarının doğruladığı hipotez hangisidir?
A) Turnusol kağıdına asit veya baz damlatılırsa renk değişimi gözlenmez.
B) Turnusol kağıdına asit damlatılırsa kırmızı renk, baz damlatılırsa mavi/mor renk alir.
C) Turnusol kağıdına asit damlatılırsa yeşil renk, baz damlatılırsa kırmızı renk alır.
D) Turnusol kağıdına asit veya baz damlatılırsa renk değişimi gözlenir.

Soru 22: Sizce bu araştırmada kontrol edilen değişken hangisidir?
A) Turnusol kâğıdının büyüklüğü
B) Madde sayıs1
C) Madde cinsi
D) Turnusol kâğıdındaki renk değişimi

Soru 23: Sizce araştırmada bağımlı değişken hangisidir?
A) Madde cinsi
B) Madde sayıs
C) Turnusol kâğıdındaki renk değişimi
D) Turnusol kâğıdı büyüklüğü

Soru 24: Sizce araştırmada bağımsız değişken hangisidir?
A) Turnusol kâğıdındaki renk değişimi
B) Madde cinsi
C) Turnusol kâğıdının ilk rengi
D) Madde sayıs1 


\section{Cevap Anahtarı}

\begin{tabular}{|l|l|l|l|l|l|}
\hline $1-\mathrm{C}$ & $2-\mathrm{D}$ & $3-\mathrm{D}$ & $4-\mathrm{B}$ & $5-\mathrm{C}$ & $6-\mathrm{C}$ \\
\hline $7-\mathrm{A}$ & $8-\mathrm{D}$ & $9-\mathrm{B}$ & $10-\mathrm{D}$ & $11-\mathrm{C}$ & $12-\mathrm{B}$ \\
\hline $13-\mathrm{D}$ & $14-\mathrm{D}$ & $15-\mathrm{A}$ & $16-\mathrm{B}$ & $17-\mathrm{A}$ & $18-\mathrm{A}$ \\
\hline $19-\mathrm{A}$ & $20-\mathrm{C}$ & $21-\mathrm{B}$ & $22-\mathrm{A}$ & $23-\mathrm{C}$ & $24-\mathrm{B}$ \\
\hline
\end{tabular}

\section{EK 2: Görüşme Soruları}

1. Değişken belirleme testini seviye olarak nasıl tanımlarsınız?

2. Değişkenleri rahatça belirleyebilmek için etkili olan faktörler sizce nedir?

a. Sana kolay gelen sorularda neden zorlanmamış olabilirsin?

b. Bu durumda başarılı olmanı neye bağlayabilirsin?

3. Soru dolaylı (daha üstü kapalı) bir şekilde sorulsa soruyu doğru cevaplandırabileceğini düşünür müsün? Soruyu daha kolay anlayıp cevaplandırmanı sağlayacak bir yol olabilir mi? Herhangi bir önerin var mı?

a. Sana zor gelen sorularda neden zorlanmış olabilirsin?

b. Bu durumda başarısız olmanı neye bağlayabilirsin?

c. Soruda bağımlı değişken yerine etkilenen/ölçülen değişken, bağımsız değişken yerine etkileyen/değiştirilen denilirse, soruyu doğru cevaplayabileceğini düşünür müsün?

4.Sorular daha açık ifade edilseydi, daha kolay cevaplandırabilir miydin? Bu durumda senin cevabın, performansın ya da başarının ne yönde değişeceğini düşünüyorsun?

5.Soruyu daha kolay anlayıp cevaplandırmanı sağlayacak bir yol olabilir mi? Herhangi bir önerin var mi?

6.Değişkenleri belirlemede kendini yeterli buluyor musun?

7.Değişken belirleme testi soruları daha önce karşılaştığınız sorulara benziyor muydu? 